\title{
Status of Fishes in Selected Adirondack Lakes: Eight Decades of Changing Assemblage Composition
}

\author{
Robert A. Daniels ${ }^{1}, *$ Robert T. Bombard ${ }^{2}$, James W. Sutherland ${ }^{2}$ and Charles W. Boylen ${ }^{3}$ \\ ${ }^{1}$ Research and Collections, New York State Museum, Cultural Education Centre 3140, Albany, New York 12230 USA \\ ${ }^{2}$ New York State Department of Environmental Conservation, 625 Broadway Avenue, Albany, New York 12233 USA \\ ${ }^{3}$ Darrin Fresh Water Institute, Rensselaer Polytechnic Institute, Troy, New York 12180 USA
}

\begin{abstract}
Twenty-six taxa of fish were present in eighteen lakes in the southwestern quadrant of the Adirondack Park, Herkimer and Hamilton Counties, New York. Species richness in the lakes ranged from 1 to 18 species. Here we assess the condition and composition of the fish assemblages in lakes and compare in-lake changes in species composition over an 80 -yr period. To examine assemblage condition we estimated population size of species in the lakes using mark-and-recapture techniques. To examine change in composition we compared the assemblage structure of these lakes to that present in two previous surveys. Populations of all but the rarest species comprised several size classes, indicating successful recruitment for all common species in all lakes. Most lakes support a rich, viable assemblage, although all but one includes, and many are dominated by, exotic species. Although the lakes studied are in one ecoregion and often in the same subdrainage, species composition differed among lakes and composition and abundance differed within lakes over time. Assessments of the fish assemblage composition in these lakes, when compared over time showed marked differences. These differences might be the result of several factors, but the presence of exotic taxa and extirpation of native fishes can explain gross changes in fish assemblage composition in these Adirondack lakes.
\end{abstract}

Keywords: Brook trout, exotic species, native species, New York, relative abundance, white sucker, yellow perch.

\section{INTRODUCTION}

Fish assemblages in lakes of the Adirondack Mountains of northeastern New York have been assessed in two synoptic surveys conducted in the twentieth century: lakes were surveyed during the 1920s and 1930s [1-5] and again in the 1980s [6]. Earlier studies on the fishes of this region date to the nineteenth century $[7,8]$. Other studies on individual lakes [9] and general reviews [10,11] provide an abundance of additional information so that the status of the fishes from a regional perspective is well understood. Despite an interest in lake fishes, little lake-specific information on fish assemblages is available. Of over 2,700 lakes larger than 0.2 ha present in the Adirondack Park, only the assemblages of the larger or the more important recreational lakes have been given more that a cursory examination.

We provide detailed information on the fish assemblages of eighteen lakes situated in the southwestern quadrant of the Adirondack Park, a forested, upland preserve in New York, USA. These lakes are part of a suite of lakes sampled as part of a study on the effects of acid deposition on the biota of the region [12]. Here we examine assemblage and population characteristics, including composition, relative abundance, population size estimates of certain species, size class strurcture and recruitment. This information quantifies assemblage health and viability, which when compared with species

*Address correspondence to this author at New York State Museum, CEC 3140, Albany, NY 12230, USA; Tel: 518-473-8121; Fax: 518-486-2034; E-mail: rdaniels@mail.nysed.gov. composition change over eight decades, provides detailed case studies on the fishes of the study lakes. The observations detailed here can be used to assess and compare conditions in other lakes in the region.

\section{MATERIALS AND METHODS}

\section{Site Description}

The Adirondacks are a mountainous region in upstate New York. Fourteen of the lakes in this study are in the headwaters of the Moose River, a tributary system of the Black River, in the Saint Lawrence River drainage (Fig. 1). Cascade, Moss, Dart and Rondaxe lakes and West, Wheeler and Round ponds are in the Middle Branch, Moose River system. Middle Branch Lake enters the Moose River through Pine Creek approximately $47 \mathrm{~km}$ downstream of Lake Rondaxe. Squaw and Limekiln lakes and Helldiver Pond enter the system via the South Branch, Moose River. South and North lakes are at the headwaters of the Black River. Sunday Lake is in the Beaver River system, also a tributary to the Black River. Sagamore Lake and Raquette Lake Reservoir also are in the Saint Lawrence River drainage, but in the headwaters of the Raquette River watershed. G Lake is a headwater lake in the West Canada Creek watershed and Willis Pond is in the Sacandaga River system, both in the Hudson River drainage.

The lakes range in elevation from $397-645 \mathrm{~m}$. All are relatively small lakes, ranging in size from $3.6-187$ ha. Most are shallow, ranging in mean depth from $1.5-13 \mathrm{~m}$, and the littoral area ranged from $2-100 \%$. See [13] for ad- 


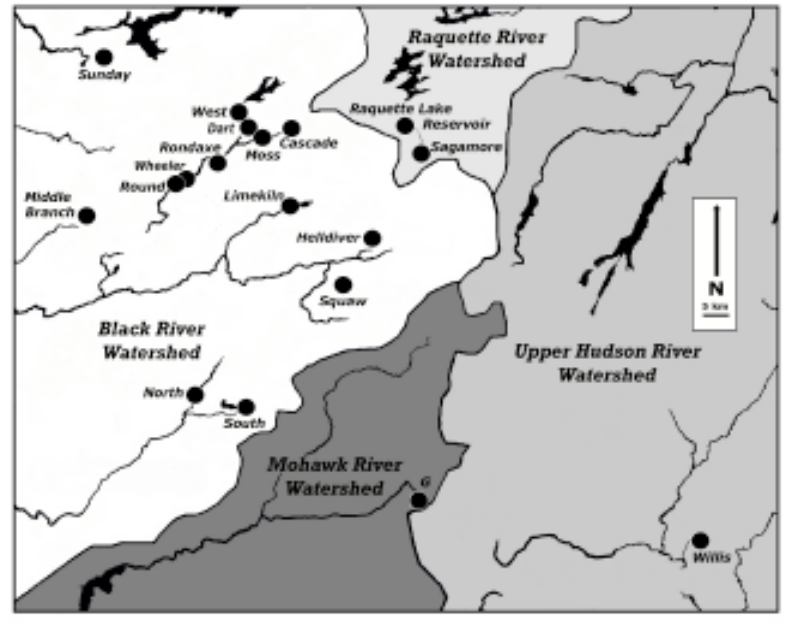

Fig. (1). Eighteen study lakes, Adirondack Mountains, upstate New York, Herkimer and Hamilton Counties. The area includes parts of four watersheds: Black and Raquette of the Saint Lawrence River drainage and Mohawk and upper Hudson of the Hudson River drainage.

ditional physical, chemical and biological information for each lake. All sample lakes are drainage lakes, i.e., there are inlet and outlet streams connecting them permanently to the rest of the watershed, except Round Pond, a seepage lake on the Middle Branch Moose River flood plane. Seepage lakes have no surface outflow and receive most of their water from direct precipitation and groundwater [14]. Lakes are classified by criteria in Newton and Driscoll [14].

\section{Methods}

Lakes were sampled between 1995 and 2006. Each lake was sampled at least once; Cascade, Rondaxe, Dart and Moss lakes were sampled multiple times (see below). Fish were collected with Adirondack or Indiana trap nets set perpendicular to shore with opening set 1-1.5 m deep [15]. The lead on Adirondack traps was $23 \mathrm{~m}$, wings $3 \mathrm{~m}$ and frame area opening $1.5 \mathrm{~m}^{2}$. The Indiana trap nets had a $14 \mathrm{~m}$ lead, 5 $\mathrm{m}$ wing and a $1.66 \mathrm{~m}^{2}$ opening. Mesh of both trap pots was 3 $\mathrm{mm}$ bar. Distance of the pot from shore depended upon the slope of the littoral area and not the maximum lead length. Sets were overnight and ranged from 15-26 h (mean $=20.6$ h). Although two net styles were use, the samples collected with Indiana nets represent $<9 \%$ of the 1543 sets in the database. Use of Indiana nets was discontinued in 2000. Our primary interest was in collecting as many fish as possible for marking, so information from fish caught in both net styles is used in the analysis. We sampled in May and June and again in September and October. Lake sampling was confined to these two cooler periods in an effort to catch fish when the lakes were not stratified and to minimize mortality due to handling stress [16]. Fish were removed from traps and placed in live cars anchored in the lake or in tubs on shore. Each fish was identified to species and measured (standard length (SL) in $\mathrm{mm}$ ). If the catch was large, after measuring several hundred individuals of each species, remaining fish were sorted by size class and counted.

After measuring, individual fish that met minimum length requirements were tagged with a numbered anchor tag set in the dorsal musculature under the dorsal fin [17]. We tagged yellow perch (Perca flavescens (Mitchill)) and white sucker (Catostomus commersonii (Lacepède)) >90 mm SL, brown bullhead (Ameiurus nebulosus (Lesueur)) $>80 \mathrm{~mm}$ SL, pumpkinseed (Lepomis gibbosus (Linnaeus)) and rock bass (Ambloplites ruprestris (Rafinesque)) $>75 \mathrm{~mm} \mathrm{SL}$, and brook trout (Salvelinus fontinalis (Mitchill)) > $100 \mathrm{~mm}$ SL. Beginning in spring 2001, we clipped the left pelvic fin of all fish caught in Moss, Dart and Rondaxe lakes that were not fitted with an anchor tag. We also clipped fins for population estimates in Sunday and North lakes, Raquette Lake Reservoir and Helldiver and Round ponds. After the initial day of sampling in each lake, we examined fish for tags or fin clips, and for tagged fish, noted the tag number and measured the fish. After processing, all fish were returned to the lake. One to three weeks later, we resurveyed the lake, identified, measured and counted each fish, and recorded the number of each anchor-tagged fish and the number of fish with fin clips.

During the first year, we held tagged fish in live cars for 2-4 h. There was no mortality and the fish were released into the lake. To assess the effect of the tag on fish mortality, we tagged fish and held them in an artificial system in a laboratory. In 1994, we tagged 28 bluegill (Lepomis macrochirus Rafinesque, SL $85-130 \mathrm{~mm}$ ) and 25 spotfin shiners (Cyprinella spiloptera (Cope), SL $85-105 \mathrm{~mm}$ ). All survived the subsequent 28 days and the experiment was terminated. We concluded that mortality due to handling and tagging was minimal. The numbered area of the anchor tags was $17 \mathrm{~mm}$ and even the smaller fish were able to function with tags and many fish tagged when at the low range for the species were caught in subsequent years.

As one measure of fish density within lakes we calculated relative abundance [18]. Because the sampling protocol did not vary during the surveys, the relative abundance, which is based on catch per unit effort (CPUE), provides an index that can be compared among lakes and within lakes over time. We did not weigh fish in the field; instead, using published length-weight relationships from Michigan [19], which matches the Adirondack Park in climate and latitude, we calculated biomass for each fish. These estimates allow comparisons among lakes and over time within lakes.

Fish population size was estimated using an adjusted Petersen estimate, $N^{*}=(M+1)(C+1) /(R+1)$, where $M=$ number of fish marked, $\mathrm{C}=$ number caught in the census sample, and $\mathrm{R}=$ number of recaptured marked fish in sample [20]. Each was a single census estimate, so only fish marked during each sampling period were included in the calculations. Because we tagged fish greater than a particular size in most lakes, our population estimates reflect this size bias. After 2001 all fish caught were marked, so estimates in these lakes include all sizes present in the lake. To compute diversity we used $H^{\prime}=\Sigma p_{i} l n p_{i}$, where $p_{i}$ is the proportion of each species in the catch.

In general, historic records were taken from surveys conducted in 1931-1934 [2-5] and 1983-1987 [6]. Other sources, such as unpublished field notes, also were used and were credited in the text. Because sampling methods and effort differed among the surveys, comparisons are based on presence and absence of species. The earlier surveyors made an 
Table 1. Relative Abundance of Fish Species Present in 18 Adirondack Lakes, Hamilton and Herkimer Counties, New York. Samples were Taken Between 1995 and 2006. + Indicates that the Species is Present, But Below 0.1\% Relative Abundance. Right Column gives the Number of Lakes, of the 18, in which the Species was Caught. Common Names in Bold are Exotic Species in Upland Adirondack Lakes [10, 21]

\begin{tabular}{|c|c|c|c|c|c|c|c|c|c|c|c|c|c|c|c|c|c|c|c|c|}
\hline Species & Common Name & $\frac{\dot{\Xi}}{\frac{d}{d}}$ & : & $\sum_{0}^{\overrightarrow{0}}$ & 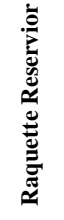 & 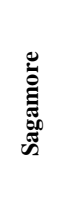 & ט & 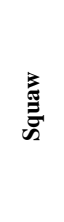 & Ë & ż: & $\stackrel{\mathscr{n}}{=}$ & 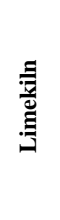 & 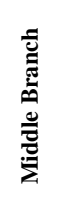 & 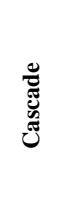 & $\stackrel{\bar{\Xi}}{\check{E}}$ & 莺 & $\hat{\sigma}^{0}$ & 气 & 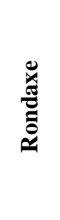 & 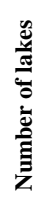 \\
\hline $\begin{array}{l}\text { Couesius } \\
\text { plumbeus }\end{array}$ & lake chub & & & & & 1.4 & & & 57.2 & & & & & & & & & & & 2 \\
\hline $\begin{array}{l}\text { Luxilus } \\
\text { cornutus }\end{array}$ & common shiner & & & & & & & & & & & & & 19.2 & & & 40.8 & 1.7 & 5.5 & 4 \\
\hline $\begin{array}{l}\text { Luxilus X } \\
\text { Semotilus }\end{array}$ & & & & & & & & & & & & & & & & & + & + & + & 2 \\
\hline $\begin{array}{c}\text { Notemigonus } \\
\text { crysoleucas }\end{array}$ & golden shiner & & 60.8 & & & & 52.8 & & & 10.4 & 8.3 & 24.0 & 1.9 & 0.1 & & 31.8 & 3.3 & 5.1 & 9.5 & 12 \\
\hline Phoxinus eos & $\begin{array}{l}\text { northern redbelly } \\
\text { dace }\end{array}$ & & & & & & & & & & & & 7.5 & & & & 0.1 & & & 2 \\
\hline $\begin{array}{c}\text { Pimephales } \\
\text { promelas }\end{array}$ & fathead minnow & & & & & & & & & & & & 22.4 & & & & & & & 1 \\
\hline $\begin{array}{c}\text { Rhinichthys } \\
\text { atratulus }\end{array}$ & blacknose dace & & & & & 0.1 & & 24.6 & & & & & & & & & + & & & 3 \\
\hline $\begin{array}{c}\text { Semotilus } \\
\text { atromaculatus }\end{array}$ & creek chub & & & & & 2.4 & & 1.4 & 0.1 & 0.1 & & 0.1 & 0.4 & 0.1 & & & 0.8 & 1.5 & 0.7 & 10 \\
\hline $\begin{array}{l}\text { Catostomus } \\
\text { catostomus }\end{array}$ & longnose sucker & & & & & 0.4 & & & & & & & & & & & & & & 1 \\
\hline $\begin{array}{c}\text { Catostomus } \\
\text { commersonii }\end{array}$ & white sucker & 36.6 & & & & 50.8 & & & & 0.7 & & + & 9.2 & 18.3 & & 0.5 & 11.1 & 16.0 & 14.8 & 10 \\
\hline $\begin{array}{c}\text { Catostomus } \\
\text { utawana }\end{array}$ & summer sucker & & & & & & & 73.7 & & & & & & & & & & & & 1 \\
\hline $\begin{array}{l}\text { Ameiurus } \\
\text { nebulosus }\end{array}$ & brown bullhead & 17.1 & 39.2 & 100.0 & 99.8 & 25.3 & 46.9 & & 41.6 & 14.4 & 1.2 & 13.6 & & 0.9 & & 35.7 & 10.6 & 7.6 & 25.2 & 15 \\
\hline Esox niger & chain pickerel & & & & & & & & & & 7.1 & & & & & 0.8 & & & & 2 \\
\hline Umbra limi & central mudminnow & 2.4 & & & & & & & & & & & 2.2 & & 3.1 & & + & + & + & 6 \\
\hline $\begin{array}{l}\text { Osmerus } \\
\text { mordax }\end{array}$ & rainbow smelt & & & & & & & & & & & & & & & & 0.3 & & + & 2 \\
\hline Salmo salar & Atlantic salmon & & & & & & & & & & & & & & & & + & & & 1 \\
\hline Salmo trutta & brown trout & & & & & & & & & & & & & & & & + & & & 1 \\
\hline $\begin{array}{l}\text { Salvelinus } \\
\text { fontinalis }\end{array}$ & brook trout & & + & & 0.2 & 2.5 & 0.3 & 0.3 & 1.0 & + & & & 0.1 & 0.2 & & & 0.1 & 0.1 & + & 12 \\
\hline $\begin{array}{l}\text { Salvelinus } \\
\text { namaycush }\end{array}$ & lake trout & & & & & & & & & & & & & & & & + & & & 1 \\
\hline $\begin{array}{l}\text { S. fontinalis } \mathrm{X} \\
\text { S. namaycush }\end{array}$ & splake & & & & & & & & & & & 4.0 & & & & & & & & 1 \\
\hline $\begin{array}{l}\text { Fundulus } \\
\text { diaphanus }\end{array}$ & banded killifish & & & & & & & & & & & 0.7 & & & & & & 0.5 & + & 3 \\
\hline $\begin{array}{c}\text { Ambloplites } \\
\text { rupestris }\end{array}$ & rock bass & & & & & & & & & & & 24.7 & & & & & + & 5.0 & 4.5 & 4 \\
\hline $\begin{array}{l}\text { Lepomis } \\
\text { gibbosus }\end{array}$ & pumpkinseed & 41.5 & & & & 3.6 & & & & & 25 & 31.2 & 56.3 & 2.4 & 96.9 & & 7.4 & 5.9 & 13.1 & 10 \\
\hline $\begin{array}{c}\text { Micropterus } \\
\text { dolomieu }\end{array}$ & smallmouth bass & & & & & & & & & & & & & & & & & + & + & 2 \\
\hline
\end{tabular}




\begin{tabular}{|c|c|c|c|c|c|c|c|c|c|c|c|c|c|c|c|c|c|c|c|c|}
\hline Species & Common Name & 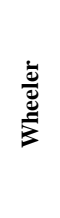 & 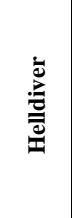 & $\sum^{\overline{0}}$ & 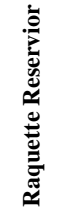 & 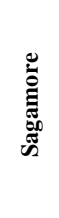 & ט & $\sum_{\bar{E}}$ & Ë & ᄅ̃ & $\stackrel{n}{3}$ & 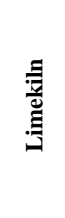 & 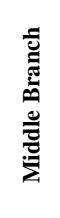 & 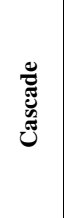 & $\begin{array}{l}\bar{B} \\
\stackrel{0}{*}\end{array}$ & 莺 & $\sum^{\infty}$ & 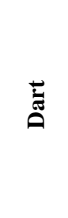 & 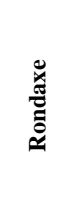 & 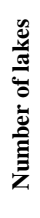 \\
\hline $\begin{array}{c}\text { Micropterus } \\
\text { salmoides }\end{array}$ & largemouth bass & 2.4 & & & & & & & & & 3.6 & & & & & & 0.2 & 0.1 & 0.4 & 5 \\
\hline $\begin{array}{c}\text { Perca flaves- } \\
\text { cens }\end{array}$ & yellow perch & & & & & 13.6 & & & & 74.4 & 54.8 & 1.6 & & 58.8 & & 26.0 & 25.0 & 56.4 & 26.1 & 9 \\
\hline $\begin{array}{c}\text { Total fish } \\
\text { caught }\end{array}$ & & 41 & 10992 & 9572 & 1404 & 788 & 1435 & 4942 & 2035 & 4552 & 84 & 3935 & 1548 & 1052 & 11434 & 992 & 65942 & 28639 & 62536 & \\
\hline $\begin{array}{c}\text { CPUE } \\
\text { (fish/hour of } \\
\text { net set) }\end{array}$ & & 0.2 & 31.9 & 52.1 & 3.8 & 2.1 & 8.5 & 22.0 & 5.1 & 7.9 & 0.3 & 5.4 & 5.1 & 2.0 & 31.8 & 2.6 & 7.1 & 3.2 & 7.2 & \\
\hline Richness & & 5 & 3 & 1 & 2 & 9 & 3 & 4 & 4 & 6 & 6 & 9 & 8 & 8 & 2 & 5 & 18 & 14 & 15 & \\
\hline Diversity H' & & 1.21 & 0.67 & 0 & 0.01 & 1.29 & 0.71 & 0.65 & 0.42 & 0.78 & 1.24 & 1.56 & 1.26 & .078 & 0.14 & 1.15 & 1.21 & 1.39 & 1.90 & \\
\hline
\end{tabular}

Table 2. Percentage Biomass of Fish Species Present in 13 Adirondack Lakes with Species Richness > 3, Hamilton and Herkimer Counties, New York. Samples were Taken Between 1995 and 2006. + Indicates that the Species is Present, but Represents < $0.1 \%$ of the Biomass. In Lakes with Three or Fewer Species, Biomass is Reported in Text

\begin{tabular}{|c|c|c|c|c|c|c|c|c|c|c|c|c|c|c|}
\hline Species & & Wheeler & Sagamore & Squaw & South & North & Willis & Limekiln & $\begin{array}{l}\text { Middle } \\
\text { Branch }\end{array}$ & Cascade & Sunday & Moss & Dart & Rondaxe \\
\hline Couesius plumbeus & lake chub & & 0.3 & & 52.1 & & & & & & & & & \\
\hline Luxilus cornutus & common shiner & & & & & & & & & 12.3 & & 14.5 & 0.5 & 1.4 \\
\hline Luxilus X Semotilus & & & & & & & & & & + & & + & + & + \\
\hline Notemigonus crysoleucas & golden shiner & & & & & 8.3 & 0.8 & 11.5 & 0.7 & 0.7 & 12.6 & 0.9 & 0.9 & 1.8 \\
\hline Phoxinus eos & $\begin{array}{l}\text { northern redbelly } \\
\text { dace }\end{array}$ & & & & & & & & 0.6 & + & & + & & \\
\hline Pimephales promelas & fathead minnow & & & & & & & & 2.9 & & & & & \\
\hline Rhinichthys atratulus & blacknose dace & & + & 5.0 & & & & & & & & + & & \\
\hline Semotilus atromaculatus & creek chub & & 0.3 & 2.0 & 0.1 & 0.1 & & + & 0.5 & 0.3 & & 0.5 & 0.7 & 0.4 \\
\hline Catostomus catostomus & longnose sucker & & 3.2 & & & & & & & & & & & \\
\hline Catostomus commersonii & white sucker & 82.4 & 75.9 & & & 2.0 & & 0.2 & 85.9 & 58.7 & 11.6 & 52.9 & 62.6 & 55.5 \\
\hline Catostomus utawana & summer sucker & & & 90.1 & & & & & & & & & & \\
\hline Ameiurus nebulosus & brown bullhead & 6.6 & 14.9 & & 44.2 & 32.6 & + & 39.9 & & 7.5 & 39.3 & 12.5 & 8.4 & 18.8 \\
\hline Esox niger & chain pickerel & & & & & & 22.8 & & & & 5.0 & & & \\
\hline Umbra limi & $\begin{array}{c}\text { central mudmin- } \\
\text { now }\end{array}$ & + & & & & & & & 0.2 & + & & + & + & + \\
\hline Osmerus mordax & rainbow smelt & & & & & & & & & & & 0.1 & & + \\
\hline Salmo salar & Atlantic salmon & & & & & & & & & & & & & \\
\hline Salmo trutta & brown trout & & & & & & & & & & & + & & \\
\hline Salvelinus fontinalis & brook trout & & 2.3 & 1.9 & 3.6 & 0.1 & & & 0.2 & 0.6 & & 0.2 & 0.4 & 0.1 \\
\hline Salvelinus namaycush & lake trout & & & & & & & & & & & + & & \\
\hline S. fontinalis X S. namaycush & splake & & & & & & & 9.2 & & & & & & \\
\hline Fundulus diaphanus & banded killifish & & & & & & & 0.2 & & & & & 0.1 & + \\
\hline Ambloplites rupestris & rock bass & & & & & & & 17.5 & & & & + & 3.2 & 3.2 \\
\hline Lepomis gibbosus & pumpkinseed & 10.8 & 1.2 & & & & 43.6 & 20.2 & 9.0 & 1.7 & & 3.3 & 2.9 & 7.7 \\
\hline
\end{tabular}


Table 2. cont....

\begin{tabular}{|c|c|c|c|c|c|c|c|c|c|c|c|c|c|c|}
\hline Species & & Wheeler & Sagamore & Squaw & South & North & Willis & Limekiln & $\begin{array}{l}\text { Middle } \\
\text { Branch }\end{array}$ & Cascade & Sunday & Moss & Dart & Rondaxe \\
\hline Micropterus dolomieu & smallmouth bass & & & & & & & & & & & & & + \\
\hline Micropterus salmoides & largemouth bass & 0.2 & & & & & 19.2 & & & & & 0.1 & 0.1 & 0.3 \\
\hline Perca flavescens & yellow perch & & 1.9 & & & 56.9 & 13.6 & 1.3 & & 18.2 & 31.5 & 15.0 & 20.2 & 10.8 \\
\hline BPUE ( $\mathrm{g} / \mathrm{hr}$ of net set) & & 59.8 & 212.8 & 318.2 & 122.9 & 114.5 & 31.9 & 239.3 & 121.6 & 174.8 & 74.0 & 261.4 & 228.1 & 209.2 \\
\hline
\end{tabular}

effort to provide a comprehensive list of species present and used a variety of gear to achieve this goal [2-6]. Specimens from earlier surveys are vouchered in museums and were reexamined if the identification was in doubt. Similarity was assessed using the Jaccard Index, $\mathrm{S}=\mathrm{a} /(\mathrm{a}+\mathrm{b}+\mathrm{c})$, where $\mathrm{a}=$ number of species common to both samples, $b=$ number of species found only in the first sample, and $\mathrm{c}=$ number of species found in the second sample only.

\section{RESULTS}

Twenty-four species and two hybrids were present in the eighteen Adirondack lakes in this study (Table 1). Brown bullhead was present in 15 lakes. White sucker, golden shiner (Notemigonus crysoleucas (Mitchill)), creek chub (Semotilus atromaculatus (Mitchill), brook trout and pumpkinseed were present in ten or more lakes. Seven taxa were taken in only one lake and another eight taxa were found in three or fewer lakes. The most abundant species in the catches were yellow perch, brown bullhead, golden shiner and pumpkinseed. Yellow perch was the most abundant species in five of the lakes in which it was present, pumpkinseed in four and brown bullhead in three lakes. In addition to these three species, four other species also were dominant by number in one or two lakes (Table $\mathbf{1}$ ).

Biomass was often dominated by white sucker; white sucker biomass exceeded $50 \%$ of total biomass in seven of the ten lakes in which it occurred (Table 2). Brown bullhead, in the 15 lakes where it was found, dominated fish biomass in six. Pumpkinseed biomass exceeded that of all other species in two lakes and yellow perch, lake chub (Couesius plumbeus (Agassiz)) and summer sucker (Catostomus utawana Mather) had greatest biomass in one lake each (Table 2).

\section{High-DOC Lakes}

Dissolved organic Carbon is an indicator of the amount of organic acid present in solution in a lake; in Adirondack lakes high-DOC waters are defined as having values $>500$ $\mu \mathrm{mol} 1^{-1}$ [14]. Five sample lakes, Wheeler, Helldiver and West ponds, Raquette Lake Reservoir and Sagamore Lake fall into this category.

In Wheeler Pond, we collected five species: white sucker, brown bullhead, central mudminnow (Umbra limi (Kirtland)), pumpkinseed and largemouth bass (Micropterus salmoides (Lecepède)) (Table 1). This lake was 6 ha with a mean depth of $3 \mathrm{~m}$. Only 41 individual fish were caught, which translates to 0.2 fish $\mathrm{h}^{-1}$. Biomass in this pond, at just under $60 \mathrm{~g} \mathrm{~h}^{-1}$ set, also was low. Interestingly, most of the fish were large: white sucker ranged from 279-386 mm SL, brown bullhead from 155-216 $\mathrm{mm}$ and pumpkinseed from 98-168 $\mathrm{mm}$. The smallest fish caught was a single central mudminnow at $50 \mathrm{~mm} \mathrm{SL}$.

Brown bullhead dominated the fish assemblages of Helldiver and West ponds and Raquette Lake Reservoir. Each lake was depauperate and had no more than three species present (Table 1).

Helldiver Pond was a 7 ha, $1.7 \mathrm{~m}$ deep lake on the Moose River Plain at an elevation of $566 \mathrm{~m}$. The assemblage was composed of golden shiner, brown bullhead and brook trout (Table 1). We collected over 10,000 individual fish in Helldiver Pond and estimated the population size of brown bullhead to be 52,050 (95\% CI: 41,770-64,850) and of golden shiner to be 48,720 (95\% CI: $45,560-52,400)$. In both species, our catch was approximately $5 \%$ of the estimate. The density estimate was 0.9 fish $\mathrm{m}^{-3}$. The size range of captured fish of both brown bullhead $(31-193 \mathrm{~mm})$ and golden shiner $(39-143 \mathrm{~mm})$ indicate that several size classes existed in the lake and annual recruitment maintained stocks. Brook trout has been stocked in Helldiver Pond but recently, brown trout (Salmo trutta Linnaeus) was the only species stocked [22].

Brown bullhead was abundant in West Pond and was the only species captured in the lake. West Pond, in the upper North Branch Moose River system, is at $585 \mathrm{~m}$ elevation and joins Moose River through Big Moose Lake. It is 10.4 ha with a mean depth of $1.5 \mathrm{~m}$. Almost 10,000 individual fish were caught during the sampling. This represented a CPUE of 54 fish $\mathrm{h}^{-1}$ net set and often over 1,000 fish per net, one of the highest of all study lakes. Brown bullhead ranged from 35-218 mm SL. Larger fish were common; $50.1 \%$ of the sample exceeded $80 \mathrm{~mm}$ SL. Brook trout has been stocked into the lake episodically, but not in recent years (New York State Department of Environmental Conservation (NYSDEC) unpubl. data).

The survey of Raquette Lake Reservoir showed that brown bullhead dominated the assemblage and brook trout was a minor component (Table 1). Brown bullhead ranged in SL from 11 to $173 \mathrm{~mm}$. Brook trout ranged from $200-231$ $\mathrm{mm}$ SL. Raquette Lake Reservoir was 1.5 ha with a mean depth of $1.6 \mathrm{~m}$ and dominated by a single species. The estimate of the population size of brown bullhead was 1,615 individuals (CI: $1,440-1,810)$. Density is 0.7 bullhead $\mathrm{m}^{-3}$. The CPUE for this lake was 4.6 fish $^{-1}$ set.

We collected nine species of fish in Sagamore Lake, a 68 ha lake at $580 \mathrm{~m}$ elevation. Sagamore Lake was the deepest lake sampled, with a maximum depth of $23 \mathrm{~m}$. White sucker dominated the assemblage; brown bullhead and yellow perch 
were the next most abundant species in our catch (Table 1). The remaining species were all relatively rare; each accounted for $<5 \%$ of the catch.

Sagamore Lake had a relatively low CPUE, at 2.1 fish $\mathrm{h}^{-1}$. We estimated that the assemblage included 554 brown bullhead > $80 \mathrm{~mm}$ SL (95\% CI: 349-923) and that the catch represented $13 \%$ of the population. Our estimate of white sucker population size was 1,613 individuals $>90 \mathrm{~mm} \mathrm{SL}$ (CI: 1,084-2,506), with $9 \%$ of the population represented in the catch. The number of yellow perch $>90 \mathrm{~mm}$ was estimated at 441 individuals (CI: 134-802). Pumpkinseed $>75$ $\mathrm{mm}$ was relatively rare, with an estimate of 60 individuals (CI: 18-109). The density of these four species, which accounted for $90 \%$ of the catch, is roughly 0.0004 fish $\mathrm{m}^{-3}$. Despite the relatively low fish density, all populations seem to be viable with individuals from at least two size classes in the eight species where more that one individual was taken. White sucker biomass dominated (Table 2) with all other species representing only a small percentage.

\section{Thin Till, Low-DOC Lakes}

Adirondack watersheds flow through glacial till and flow paths often are controlled by the thickness of the till [14]. Certain chemical parameters, like acid neutralizing capacity and $\mathrm{Ca}^{2+}$, are correlated to the thickness of the till in the lake basin. Lakes in basins with thin till have lower buffering capacity and are more sensitive to acidification [14]. Thin till drainage lakes are those with $<50 \mu \mathrm{mol}^{-1} \mathrm{Ca}$ [14]. Four lakes meet the thin till, low-DOC characteristics: G, Squaw, South and North lakes.

G Lake, in the Hudson River drainage, was 39 ha and sits at $619 \mathrm{~m}$. Golden shiner and brown bullhead represented over $99 \%$ of the catch and were $97 \%$ by weight; brook trout was relatively rare. Although brown bullhead was well represented in the catch, with 673 caught, individuals large and robust enough to tag were relatively rare and accounted for less than $10 \%$ of the catch so population size was not estimated.

Length measurements of brown bullhead ranged from 38$203 \mathrm{~mm}$. Golden shiner ranged in SL from 45-137 mm. Both species were represented by several size classes, which suggested successful recruitment. Brook trout in the sample ranged between 192-218 mm. Brook trout is stocked annually (brown trout has also been stocked in recent years) [22]. CPUE was 8.4 fish $\mathrm{h}^{-1}$.

Squaw Lake is an isolated, remote lake on a tributary of the South Branch of the Moose River. At 645 m, it was the highest altitude lake in the sample and is upstream of barrier falls. Its outlet stream drops $87 \mathrm{~m}$ in $1.7 \mathrm{~km}$. We found four species in the lake. Summer sucker was most common and represented about $75 \%$ of the catch (Table 1) and $90 \%$ by weight (Table 2). The remaining species were, in order of abundance, blacknose dace (Rhinichthys atratulus (Hermann), creek chub and brook trout (Table 1). We estimated the population size of summer sucker over $90 \mathrm{~mm} \mathrm{SL}$ to be 6,100 individuals (95\% CI: 4,295-8,970). Standard lengths for summer sucker ranged from 39-245 mm. This population is dominated by individuals less than $130 \mathrm{~mm}$ SL; only $6.4 \%$ of the individuals examined exceeded 130 $\mathrm{mm}$. These small fish were shedding milt or were gravid, which indicated that they were reproductively active during the late June sampling period. The creek chub population was estimated at 245 individuals (95\% CI: 110-612). Standard lengths for this species were between 55-160 mm. Blacknose dace had standard lengths between 47-83 $\mathrm{mm}$ and brook trout were between 131-282 mm. Successful recruitment seemed likely in all four species.

South and North lakes are two impoundments on the upper Black River that are regulated for flood control and flow augmentation. They were 197 ha and 177 ha respectively with mean depths of $13 \mathrm{~m}$ and $5.7 \mathrm{~m}$ respectively. South Lake is at an elevation of $620 \mathrm{~m}$ and North sits at $555 \mathrm{~m}$.

We collected four species in South Lake. Lake chub and brown bullhead dominated the assemblage and accounted for $98 \%$ of the catch (Table 1). Brook trout was common and creek chub was rare. We estimated the population of brown bullhead $>80 \mathrm{~mm}$ SL in South Lake to be 21,500 (95\% CI: $9,600-53,740)$. Our brown bullhead catch represented $2 \%$ of the estimated population. With this population estimate, there is 0.0028 brown bullhead $\mathrm{m}^{-3}$ in the lake. Brown bullhead recruitment is annual in South Lake with size classes with modal lengths of 40, 65, 95, 130 and $153 \mathrm{~mm} \mathrm{SL}$. Standard lengths range from 34-230 mm. Lake chub also show successful annual recruitment with three size classes with modal lengths of 60,87 and $99 \mathrm{~mm}$. Lake chub ranged from 55 to $119 \mathrm{~mm}$. Representatives from several size classes of brook trout were also present. Standard lengths for brook trout ranged from $67-255 \mathrm{~mm}$. We caught $4.8 \mathrm{fish} \mathrm{h}^{-1}$ of set in South Lake (Table 1) and BPUE was $122.9 \mathrm{~g} \mathrm{~h}^{-1}$ (Table 2).

North Lake had six species: brown bullhead, golden shiner, creek chub, white sucker, brook trout and yellow perch (Table 1), but yellow perch dominated the catch with a relative abundance of $74.4 \%$. We estimated the population size of yellow perch to be 42,850 individuals (95\% CI between 34,000 and 62,000). The brown bullhead estimate is 1,560 individuals $(95 \% \mathrm{CI}: 1,075-2,365)$ and the estimate for golden shiner is 12,865 (95\% CI: $5,250-32,000)$. This suggests that density of these species in the lake is about 0.006 fish $\mathrm{m}^{-3}$. Biomass estimates also indicate that yellow perch is dominant (Table 2). Multiple size classes were present for brown bullhead (SL size range: 111-258 mm), golden shiner $(68-128 \mathrm{~mm})$, white sucker $(141-286 \mathrm{~mm})$ and yellow perch (68-303 mm).

\section{Intermediate Till, Low-DOC Lakes}

Lakes with basins in intermediate till are differentiated by $\mathrm{Ca}$ values between 50 and $75 \mu \mathrm{mol} \mathrm{l}^{-1}$, and are less sensitive to acidification [14]. We sampled six lakes in this category: Willis, Limekiln, Middle Branch, and Cascade lakes, Round Pond and Sunday Lake.

Willis Lake, at $397 \mathrm{~m}$, is the lowest elevation lake in the sample. It is 39 ha and averages $1.6 \mathrm{~m}$ in depth. The fish assemblage in Willis Lake included golden shiner, brown bullhead, chain pickerel, pumpkinseed, largemouth bass and yellow perch. Yellow perch and pumpkinseed made up 80\% of the catch (Table 1) and over 50\% of fish biomass (Table 2). Fish were not collected in sufficient numbers to estimate population size for any species and CPUE, at 0.3 fish $\mathrm{h}^{-1}$, and 
BPUE at $31.9 \mathrm{~g} \mathrm{~h}^{-1}$, are among the lowest of the lakes sampled.

Limekiln Lake was among the largest (187 ha) and deepest (maximum depth $22 \mathrm{~m}$ ) lakes sampled in this study. The catch included nine species, with two centrarchids, pumpkinseed and rock bass, representing over $50 \%$ of the individuals in the catch (Table 1) and over $45 \%$ of the biomass (Table 2). Golden shiner, brown bullhead and splake (Salvelinus fontinalis X S. namaycush) accounted for an additional $40 \%$ of the catch. The remaining four species were rare. We estimated the population sizes of the three species representing $70 \%$ of the catch. The lake held 1,900 brown bullhead $>80$ mm SL (95\% CI: $1,015-3,880)$; our catch was $2 \%$ of the estimate. Rock bass $>75 \mathrm{~mm}$ SL was estimated to number 3,250 individuals (CI: 2,544-4,148) and our catch was $13.8 \%$ of the estimate. Pumpkinseed was the most abundant fish with an estimate of 10,095 individuals (CI: 6,730-15,860); our catch was $3 \%$ of the estimate. Estimated fish density of these three species was low at 0.001 fish $\mathrm{m}^{-3}$.

The range of standard lengths for pumpkinseed was 11$226 \mathrm{~mm}$ and young-of-year, juveniles and adults were present in the lake. Rock bass ranged in standard length from 56-205 mm. Brown bullhead ranged from 69-340 mm SL. Golden shiner standard lengths were between 70 and 197 $\mathrm{mm}$ and yellow perch were between 73 and $183 \mathrm{~mm}$. In all species, several size classes appeared to be present. CPUE was $5.5 \mathrm{fish} \mathrm{h}^{-1}$ and BPUE was $239.3 \mathrm{~g} \mathrm{~h}^{-1}$.

Middle Branch Lake was 17 ha, had a mean depth of 2.1 $\mathrm{m}$ and an elevation of $494 \mathrm{~m}$. We caught eight species; pumpkinseed dominated the assemblage (Table 1). Fathead minnow (Pimephales promelas Rafinesque) was the second most common species in the catch, followed by white sucker and northern redbelly dace (Phoxinus eos (Cope)). The other four species, brook trout, creek chub, golden shiner and central mudminnow, were rare. Our estimate of the white sucker population was 812 individuals (95\% CI: 330-2,030); our catch was $6 \%$ of the estimated population size. Standard lengths ranged from $69-355 \mathrm{~mm}$ indicating the presence of several size classes. Although white sucker accounted for only $9 \%$ of the catch (Table 1), it represented over $85 \%$ of the biomass in the catch (Table 2). We were unable to assess the pumpkinseed population size because most individuals were below the 75-mm SL needed to insert the tag. The size range for pumpkinseed in Middle Branch Lake was 25-103 $\mathrm{mm}$ SL; however, the portion of the catch greater than our minimum tagging size was $2.5 \%$. Modal standard lengths for the smaller size classes were 30,50 and $76 \mathrm{~mm}$. Most of the individuals $>35 \mathrm{~mm}$ SL were either shedding milt or obviously gravid. This population was stunted. Pumpkinseed represented over $55 \%$ of the catch (Table 1), but only $9 \%$ by weight (Table 2). Creek chub, central mudminnow and golden shiner length ranges were $92-153 \mathrm{~mm}, 25-94 \mathrm{~mm}$ and 45-103 $\mathrm{mm}$ respectively. Lengths for fathead minnow ranged from 40-66 and for northern redbelly dace from 42-64 mm.

Cascade Lake was 40 ha and had a mean depth of $4.2 \mathrm{~m}$. We found eight species in Cascade Lake during two sampling events in 1995 and 2004. Yellow perch was dominant (Table 1); white sucker and common shiner were common and the remaining five species were rare. Although yellow perch was the most frequently captured fish in our survey, we tagged relatively few individuals since most were below our minimum tagging size. There were no recaptures. Individuals in this species ranged from 49-209 $\mathrm{mm}$ SL. The strongest size class was centered at $60 \mathrm{~mm} \mathrm{SL}$. There also were two additional classes with modes at 102 and $140 \mathrm{~mm}$ SL. The white sucker population estimate was 1,785 individuals > $90 \mathrm{~mm}$ SL $(95 \%$ CI: 730-4,460). Our catch represented $3 \%$ of the estimate. White sucker standard lengths ranged between 67-390 mm. Common shiner ranged between 61-133 mm SL and two size classes were apparent, with SL centered at 89 and $119 \mathrm{~mm}$. Brown bullhead and brook trout had standard length ranges of $46-172 \mathrm{~mm}$ and $142-231 \mathrm{~mm}$ respectively. The remaining three species were represented by one individual each (Table 1).

Round Pond was a seepage pond with two species, pumpkinseed and central mudminnow. The former species was dominant with a relative abundance of $97 \%$ (Table 1) and made up $97.8 \%$ of fish biomass in the lake (Table 2). Round Pond was the smallest sample lake at 3.6 ha and relatively shallow with a mean depth of $3 \mathrm{~m}$. These attributes made the lake ideal for estimating the population size in that this pond was easily netted and the low richness allowed for a minimal handling time per fish. The resultant population estimate of pumpkinseed was 18,600 fish (95\% confidence interval (CI): $16,630-20,790)$. The $\mathrm{CI}$ is relatively narrow and the catch represented $59 \%$ of the estimate, indicating that the lake was relatively well sampled. We estimated that density at 0.17 pumpkinseed $\mathrm{m}^{-3}$. Too few central mudminnow were caught to estimate population size, but it was a minor component of the assemblage (Table 1). The pumpkinseed population was stunted: females were gravid at 35 $\mathrm{mm}$ SL; males at $30 \mathrm{~mm}$ SL were shedding milt. Mean SL for pumpkinseed in the sample of 1,659 measured individuals was $46.5 \mathrm{~mm}$ and ranged from $26-146 \mathrm{~mm} ; 62 \%$ had an SL $<51 \mathrm{~mm}$ and $0.3 \%$ had an SL > $100 \mathrm{~mm}$, suggesting at least four size classes with successful recruitment.

Sunday Lake is an 8 ha, headwater lake. We collected five species: brown bullhead, white sucker, golden shiner, chain pickerel (Esox niger Lesueur) and yellow perch. Population estimates for the three abundant species, which represent over $98 \%$ of the catch (Table 1), indicate that fish density in the lake is 0.05 fish $\mathrm{m}^{-3}$. We estimated the brown bullhead population at 2,285 individuals (95\% CI: 1,296$4,411)$. Golden shiner numbers were estimated at 3,150 $(1,564-6,891)$ and we estimated yellow perch population size at 4,705 (1,426-8,553). Brown bullhead and yellow perch accounted for $80 \%$ of the fish biomass in the lake (Table 2 ). Biomass per hour of net set (BPUE) was a low at $74.0 \mathrm{~g} \mathrm{~h}^{-1}$.

\section{Long-Term Study Lakes}

Much of the effort of this twelve-year survey was concentrated on three lakes that are linked by short stream stretches in the Middle Branch Moose River system: Moss, Dart and Rondaxe lakes (Fig. 1). All are low-DOC lakes; Dart Lake is in thin till and Rondaxe and Moss lakes are intermediate till.

We caught 18 taxa in Moss Lake in 12 years of sampling (Table 1). Nine species make up the core assemblage with each taken most years (Figs. 2 and 3). The remaining taxa 

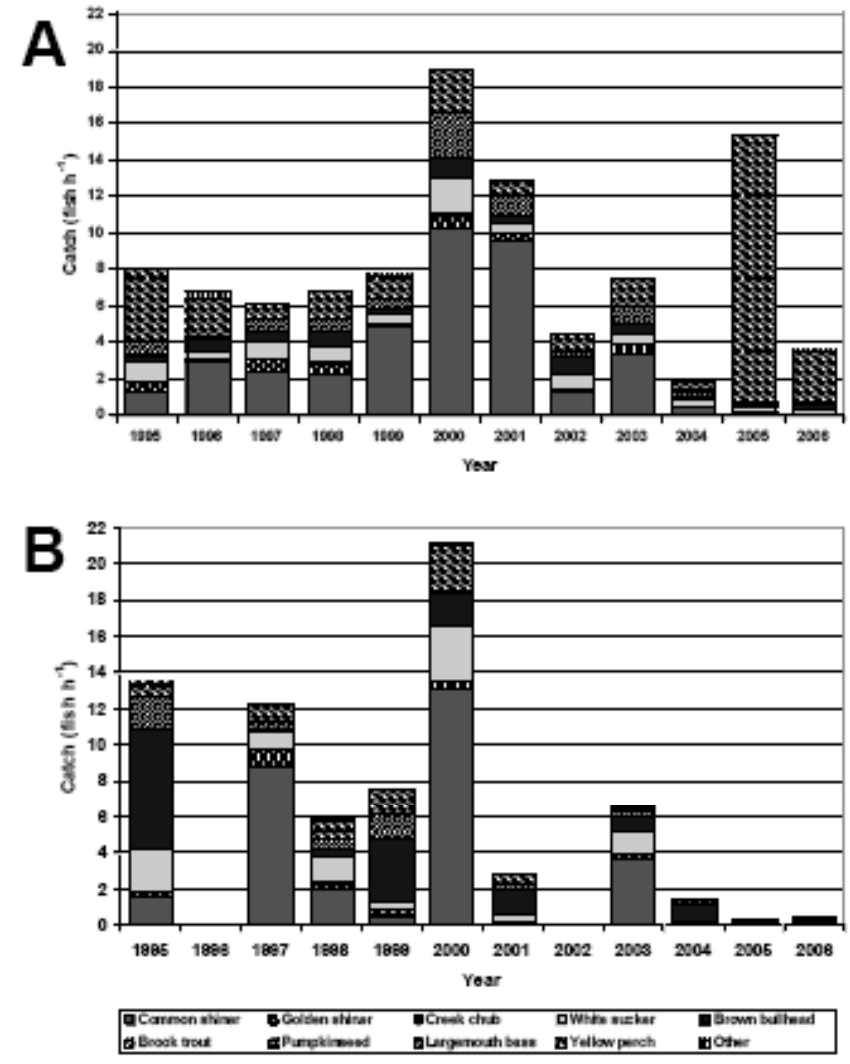

Fig. (2). Catch (number of individuals/hr) of species in Moss Lake, Herkimer County, New York, 1995-2006. A. Spring catches. B. Autumn catches.

were collected during one to four years; no one sampling event yielded more than 13 taxa. Common shiner was the dominant component of the assemblage and it held that position during several years of sampling. Yellow perch is the second most frequently encountered fish, followed by white sucker and brown bullhead. Creek chub, golden shiner, brook trout, rainbow smelt (Osmerus mordax (Mitchill)) and pumpkinseed rarely exceeded $10 \%$ of the catch in any year or season; they were consistently taken, however.

Annual and seasonal differences in the catch are apparent (Figs. 2 and 3). Although the components of the assemblage were consistent, relative abundance was not stable. Some species were taken episodically and were temporary components of the lake assemblage. Two species, brown trout and Atlantic salmon (Salmo salar Linnaeus), were released; the lone brown trout caught had a pelvic-fin clip; the Atlantic salmon individuals were discarded brood stock. Beginning in 1898, brook trout and lake trout (Salvelinus namaycush (Walbaum)) have been stocked irregularly but no game fish are currently stocked [22]. Other species, northern redbelly dace, blacknose dace, and central mudminnow, are abundant in inlet and outlet streams [23] and apparently move into the lake. Persistent, but relatively rare components of the assemblage, specifically creek chub, rainbow smelt and brook trout, show little change in relative abundance (Figs. 2 and $\mathbf{3}$ ) either annually or seasonally. Rock bass and largemouth bass, caught for the first time in 2003, may be entering the lake from the downstream Lake Rondaxe (see below) and
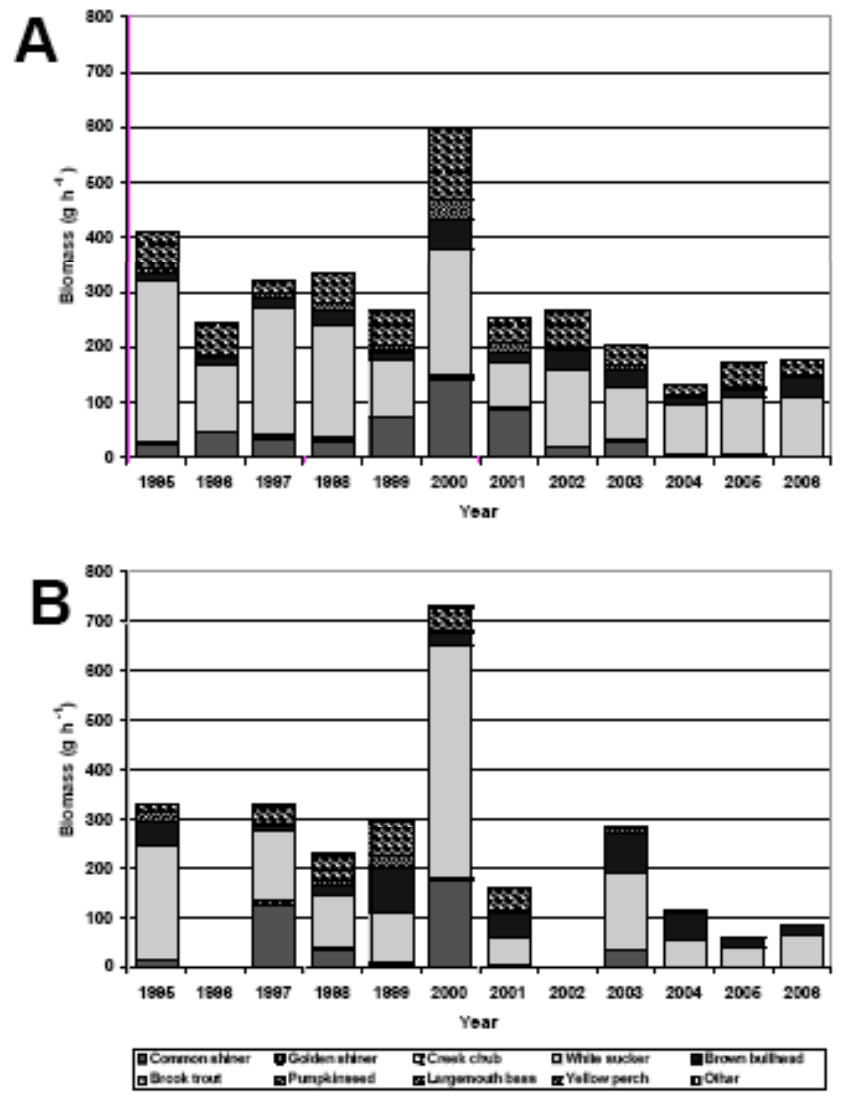

Fig. (3). Biomass $\left(\mathrm{g} \mathrm{h}^{-1}\right)$ of species in Moss Lake, Herkimer County, New York, 1995-2006. A. Spring weights. B. Autumn weights.

largemouth bass continued to increase in number during subsequent years. Golden shiner and pumpkinseed relative abundance fluctuated seasonally and annually from less than $1 \%$ to over $15 \%$. Brown bullhead and yellow perch relative abundance, mainstays of the assemblage, fluctuated from highs near $50 \%$ to lows below 5\%. Brown bullhead was often more abundant in autumn catches and yellow perch abundance was higher in spring. White sucker, with relative abundance between $10-20 \%$, and common shiner, with generally high abundance, were the members of the assemblage with the least variation in number.

Typical CPUE was 6-12 fish $\mathrm{h}^{-1}$. The anomalous years were 2000 when 20 fish $^{-1}$ were caught and 2002 when the catch was less than 5 fish $\mathrm{h}^{-1}$. After the establishment of largemouth bass, catches the column-dwelling species, such as common shiner and yellow perch, declined (Figs. 2 and 3).

Estimates of population size were not always concordant with the relative abundance. White sucker was the most stable component of the assemblage, with most estimates indicating that from 1,000-2,500 individuals > $90 \mathrm{~mm} \mathrm{SL}$ inhabit the lake (Table 3). The estimates of brown bullhead consistently indicate that relatively few individuals, less than 1,500 , are present in the lake although relative abundance, which is similar to that of white sucker, suggests that this species is more common or more susceptible to capture. 
Table 3. Estimates of Population Size, by Species, in Moss Lake, Herkimer County, New York, 1995-2006

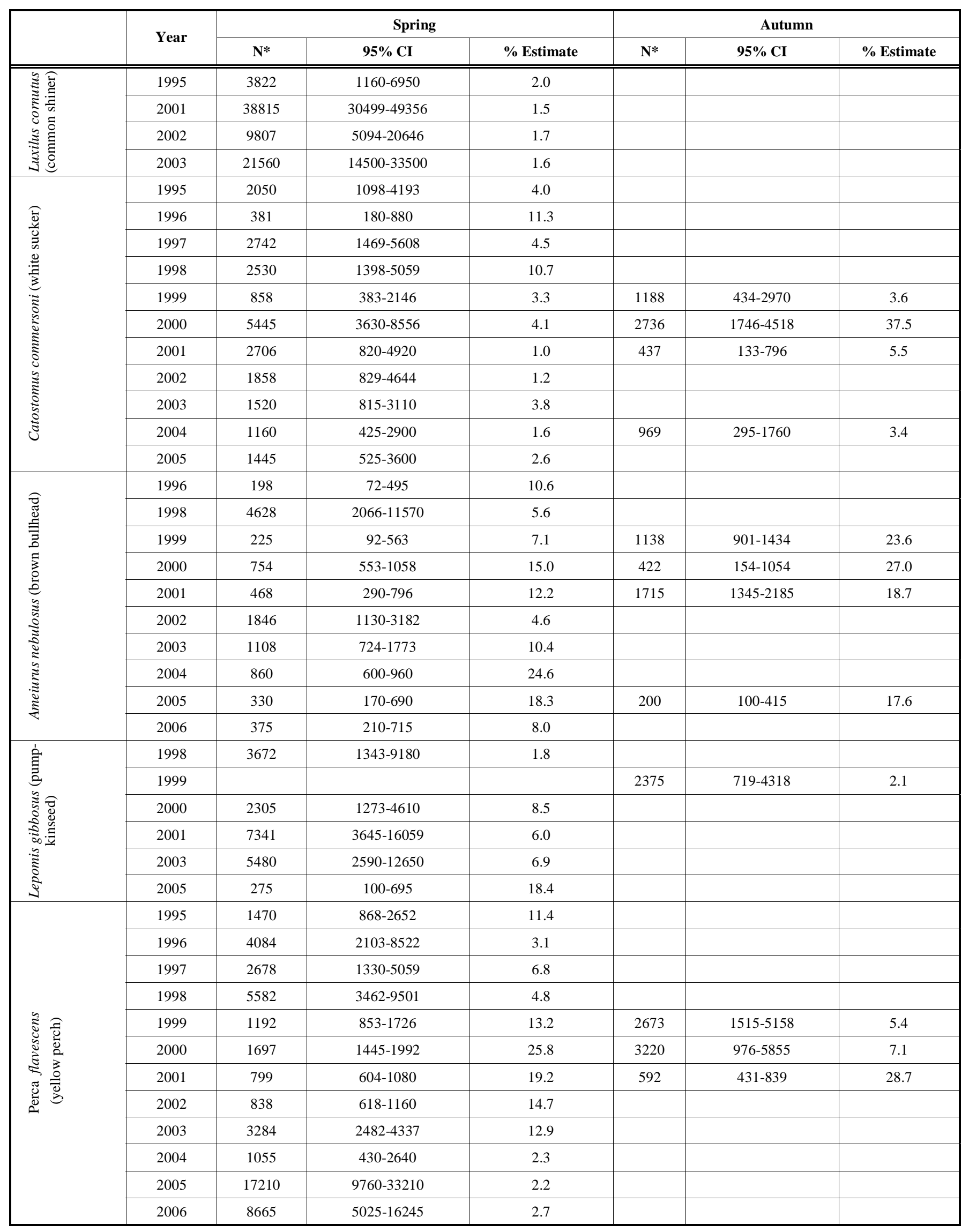



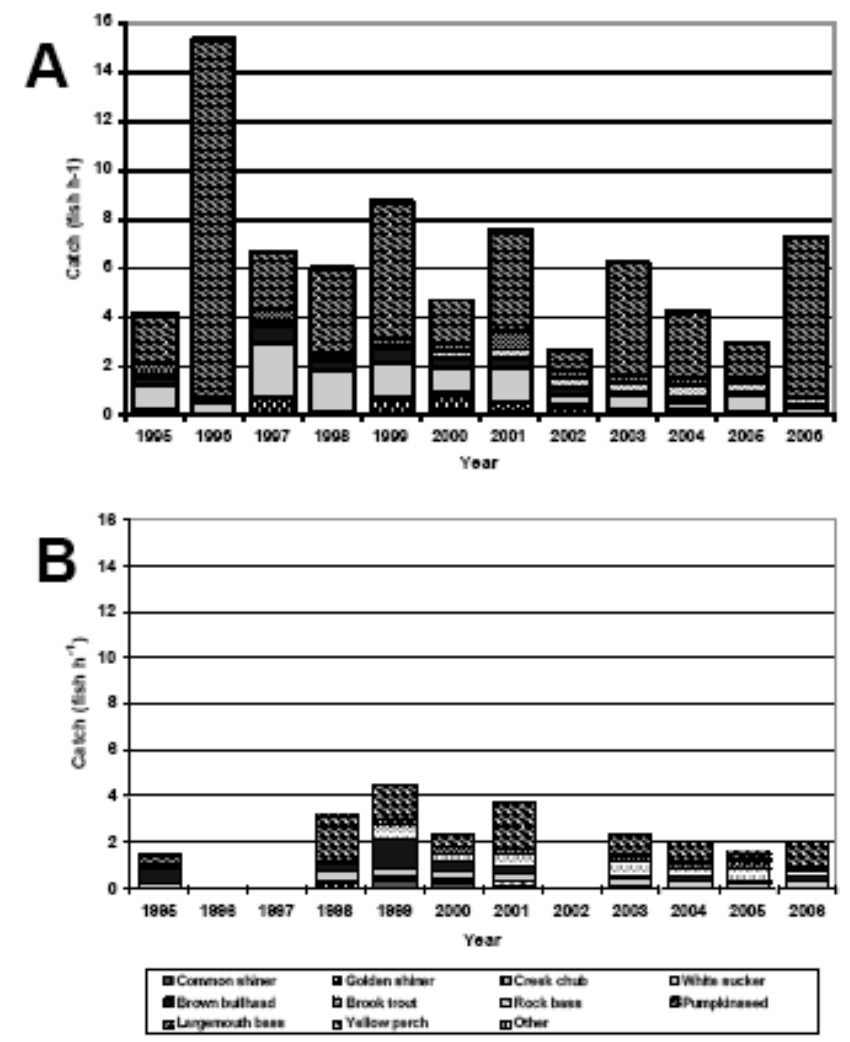

Fig. (4). Catch (number of individuals $\mathrm{h}^{-1}$ ) of species in Dart Lake, Herkimer County, New York, 1995-2006. A. Spring catches. B. Autumn catches.

Yellow perch estimates also do not reflect their relative abundance in the catch. The estimates range from 600 to over 17,000 fish. The pumpkinseed population size was difficult to estimate because relatively few fish were tagged. When relative abundance exceeded $10 \%$, estimates were possible and ranged between 275-7,400 individuals. Consistent with the relative abundance data, common shiner was extremely abundant in Moss Lake, with estimated populations between 3,800-38,800 individuals. In later years, catches of common shiner were too small to attempt population estimates.

The common species in the lake are represented by several size classes based on the ranges of lengths. This indicates that during the sampling period, successful spawning occurred annually in all species. Common shiner, for example, showed three relatively consistent size classes centered on 50, 80 and $120 \mathrm{~mm} \mathrm{SL}$ in the spring, and 80 and $130 \mathrm{~mm}$ in the autumn. The minimum size reflects a sampling bias in most cases and not the minimum size of the fish in the lake. An unusually large catch of yellow perch in spring 2005 was made up of yearling fish: $98 \%$ of the yellow perch catch was less than $75 \mathrm{~mm} \mathrm{SL}$.

We caught representatives of 14 taxa in Dart Lake (Table 1). Ten species were taken during at least ten of the twelve annual samples (Figs. 4 and 5). Largemouth bass was first taken in 2000 and remained a part of the assemblage in subsequent years. The remaining three taxa, common shinercreek chub hybrid, central mudminnow and smallmouth bass (Micropterus dolomieu Lecepède), were taken rarely. Yellow perch was consistently the dominant species in the catch, particularly in spring samples where it often exceeded $50 \%$ relative abundance (Table $\mathbf{1}$ ) and $20 \%$ by weight (Table 2 ). Yellow perch, white sucker, brown bullhead, pumpkinseed and rock bass, composed over $80 \%$ of the catch in most years.
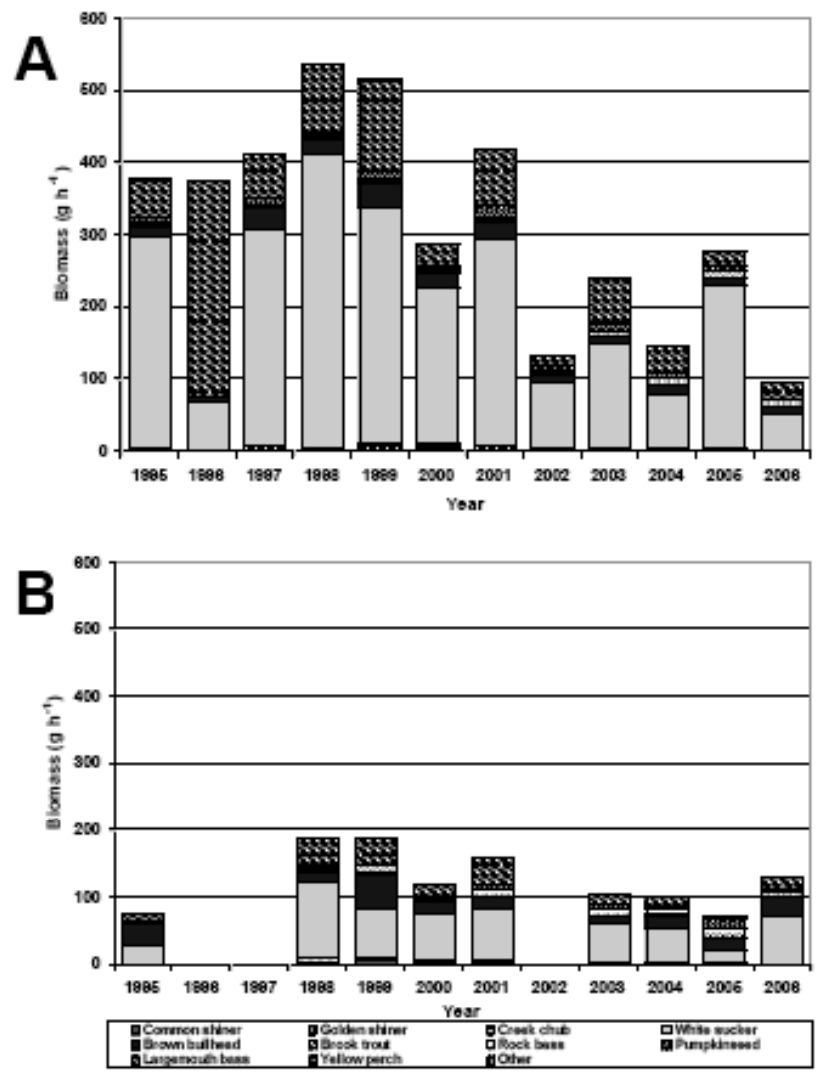

Fig. (5). Biomass $\left(\mathrm{g} \mathrm{h}^{-1}\right)$ of species in Dart Lake, Herkimer County, New York, 1995-2006. A. Spring weights. B. Autumn weights.

The relative abundance of the common species in Dart Lake was relatively consistent. Yellow perch typically represented about $50 \%$ of the catch, white sucker usually ranged between $15-25 \%$, and brown bullhead usually represented 5$10 \%$ of the catch (Figs. 4 and 5). Pumpkinseed and rock bass showed seasonal variation; both species were more prevalent in autumn catches. Annual variation was also obvious with a steady increase in abundance in rock bass over the years. Minnows compose a minor part of the assemblage and only occasionally exceeded $10 \%$ of the catch. Of the three minnow taxa, golden shiner is the dominant. Central mudminnow and banded killifish (Fundulus diaphanus (Lesueur)) were minor components of the assemblage. Largemouth and smallmouth bass were recent arrivals that may have dispersed into the lake from downstream (see below) or upstream stocking efforts. Spring CPUE ranged from less than 3 fish $\mathrm{h}^{-1}$ to over 16 fish $\mathrm{h}^{-1}$. There was a consistent seasonal difference in catch, with autumn catches always less than spring CPUE.

Population estimates for brown bullhead and pumpkinseed were relatively consistent with each other over the twelve-year period (Table 4). White sucker numbers remained relatively constant for the first seven years of the study, but numbers fluctuated after 2002. Yellow perch, which ranged between 2,300 and 46,205 individuals, showed 
Table 4. Estimates of Population Size, by species, in Dart Lake, Herkimer County, New York, 1995-2006

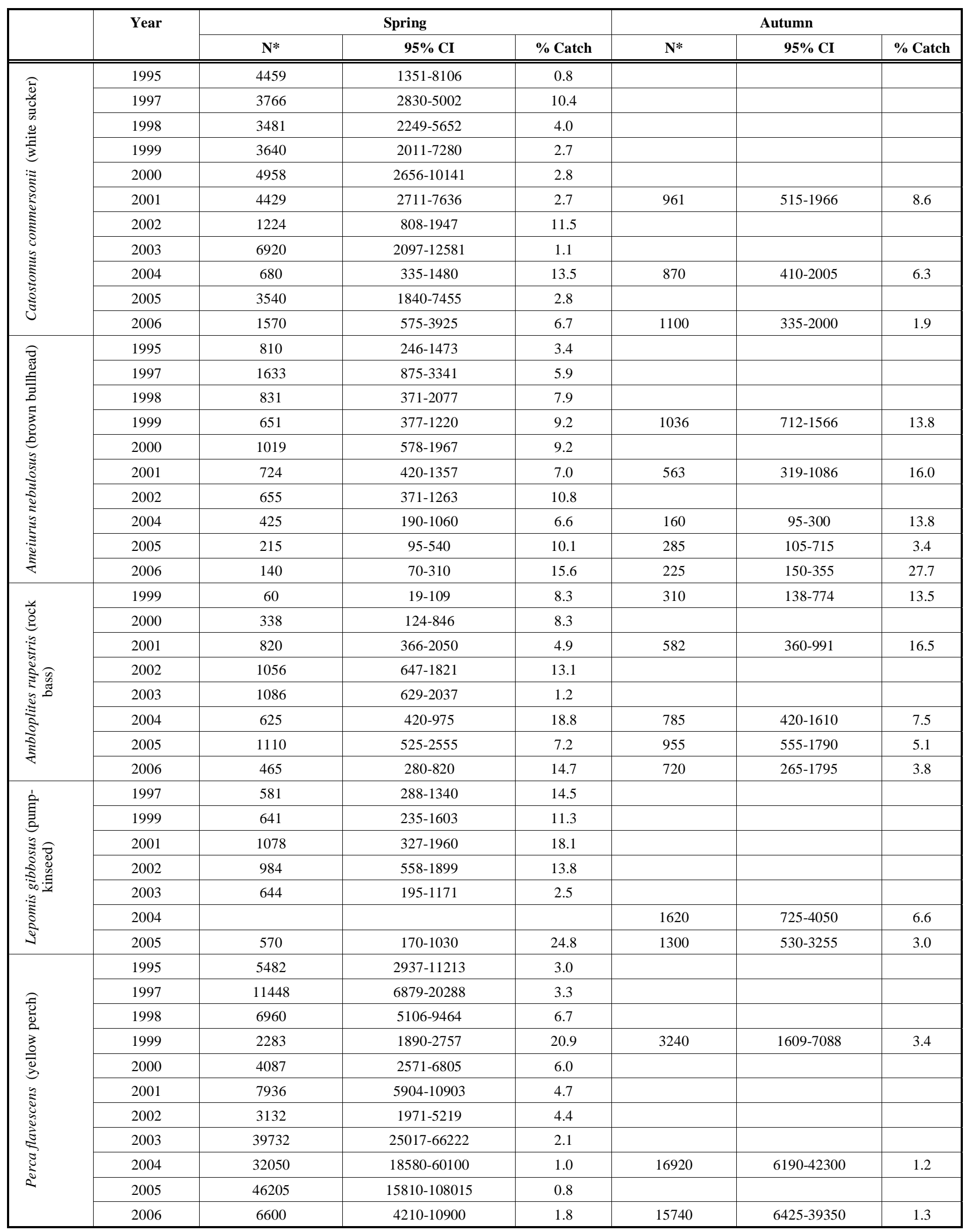



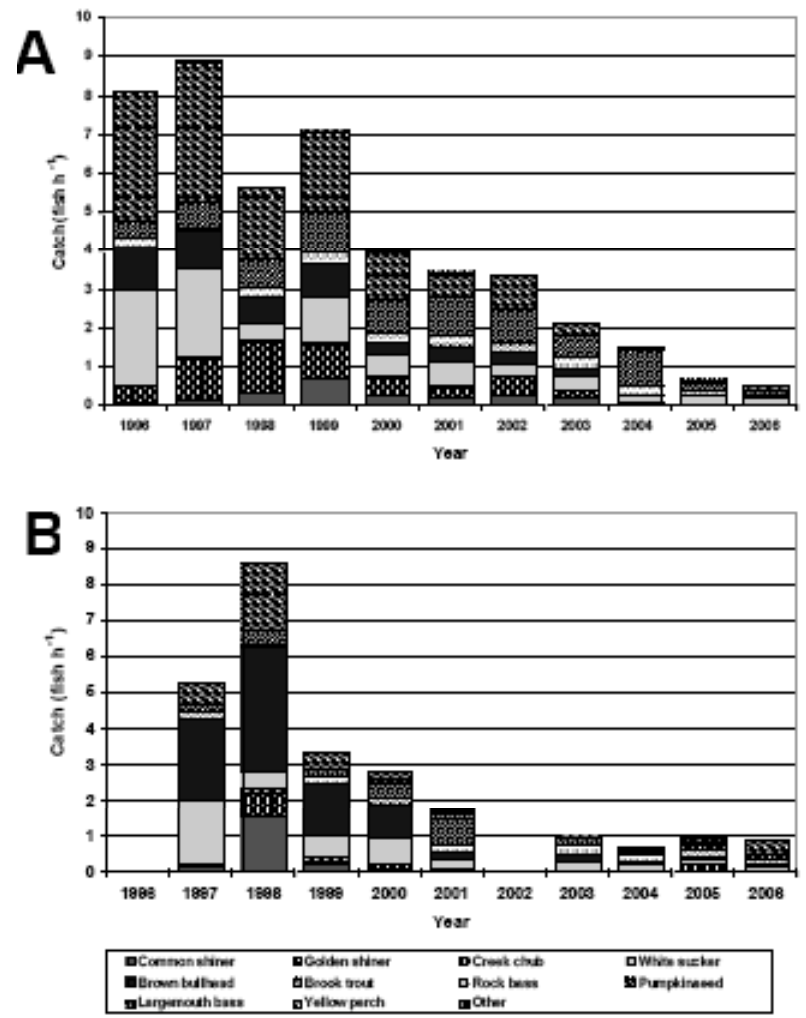

Fig. (6). Catch (number of individuals $\mathrm{h}^{-1}$ ) of species in Lake Rondaxe, Herkimer County, New York, 1996-2006. A. Spring catches. B. Autumn catches.

more variation than any other species. Rock bass estimates showed a steady increase in number of individuals, but like other species fluctuated more in the last four years of the study. Differences in abundance between spring and autumn, with some exceptions, also were relatively consistent. In general, the population estimates matched the relative abundance in that yellow perch dominated the assemblage and white sucker, brown bullhead and the sunfishes followed in order of importance.

Each of the common species in the lake was represented by multiple size classes, which is an indication of successful reproduction in each species. Even the relatively rare minnows are represented in most years by individuals in two or more size classes.

The fifteen-taxa assemblage of Lake Rondaxe is similar to that found in neighboring Moss and Dart lakes (Table 1). Eight species were consistently taken throughout the study and a ninth, largemouth bass, increasingly was important during the last five years of the study (Figs. 6 and 7). Largemouth bass was introduced into the lake in 1998 as 500 fingerlings; an additional 500 fingerlings were stocked in 1999. Although yellow perch is the most frequently caught species in the lake, dominance varied between yellow perch and brown bullhead on an annual and seasonal basis. White sucker, however, always dominated the catch by weight (Table 2) and white sucker and pumpkinseed relative abundance also approached values near those of the previous two species on occasion.
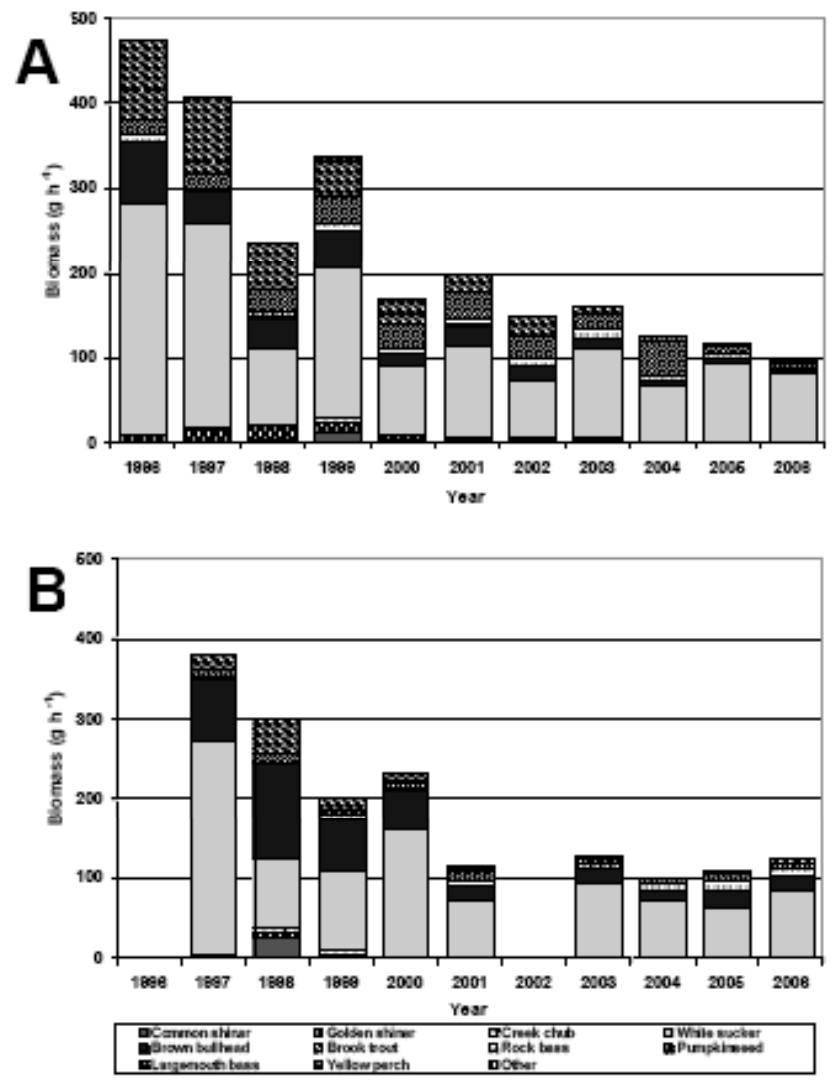

Fig. (7). Biomass $\left(\mathrm{g} \mathrm{h}^{-1}\right)$ of species in Lake Rondaxe, Herkimer County, New York, 1996-2006. A. Spring weights. B. Autumn weights.

In Lake Rondaxe, relative abundance varied annually and seasonally for all common species (Figs. 6 and 7). This pattern was characteristic of common shiner, white sucker, brown bullhead, pumpkinseed and yellow perch. Creek chub and banded killifish abundance was consistently low. Only rock bass abundance consistently increased over time. Seasonal trends were more pronounced. Yellow perch and the sunfishes represented a larger part of the catch in spring whereas brown bullhead was more prevalent in autumn. CPUE showed a steady decline during the eleven-year sampling program. During the earlier years, catch ranged from 5$10 \mathrm{fish}^{-1}$. In the last three years, catch never exceeded 5 fish $\mathrm{h}^{-1}$.

Population estimates for yellow perch show a steady decline from a high of over 15,000 individuals $>90 \mathrm{~mm}$ SL in 1997 to 580 individuals in spring, 2003 (Table 5). The decline in yellow perch numbers was matched in its relative abundance in the catch. Estimates for the number of white suckers varied annually, and this species also showed sharp declines in numbers in the later survey years. Rock bass and pumpkinseed remained relatively constant initially but also declined late in the survey. Brown bullhead showed a steady rise in numbers and then a rapid decline. As observed in Moss and Dart Lakes, each of the species was present in multiple size classes each year, indicating that recruitment of each of the species was annually successful. 
Table 5. Estimates of Population Size, by Species, in Lake Rondaxe, Herkimer County, New York, 1996-2006

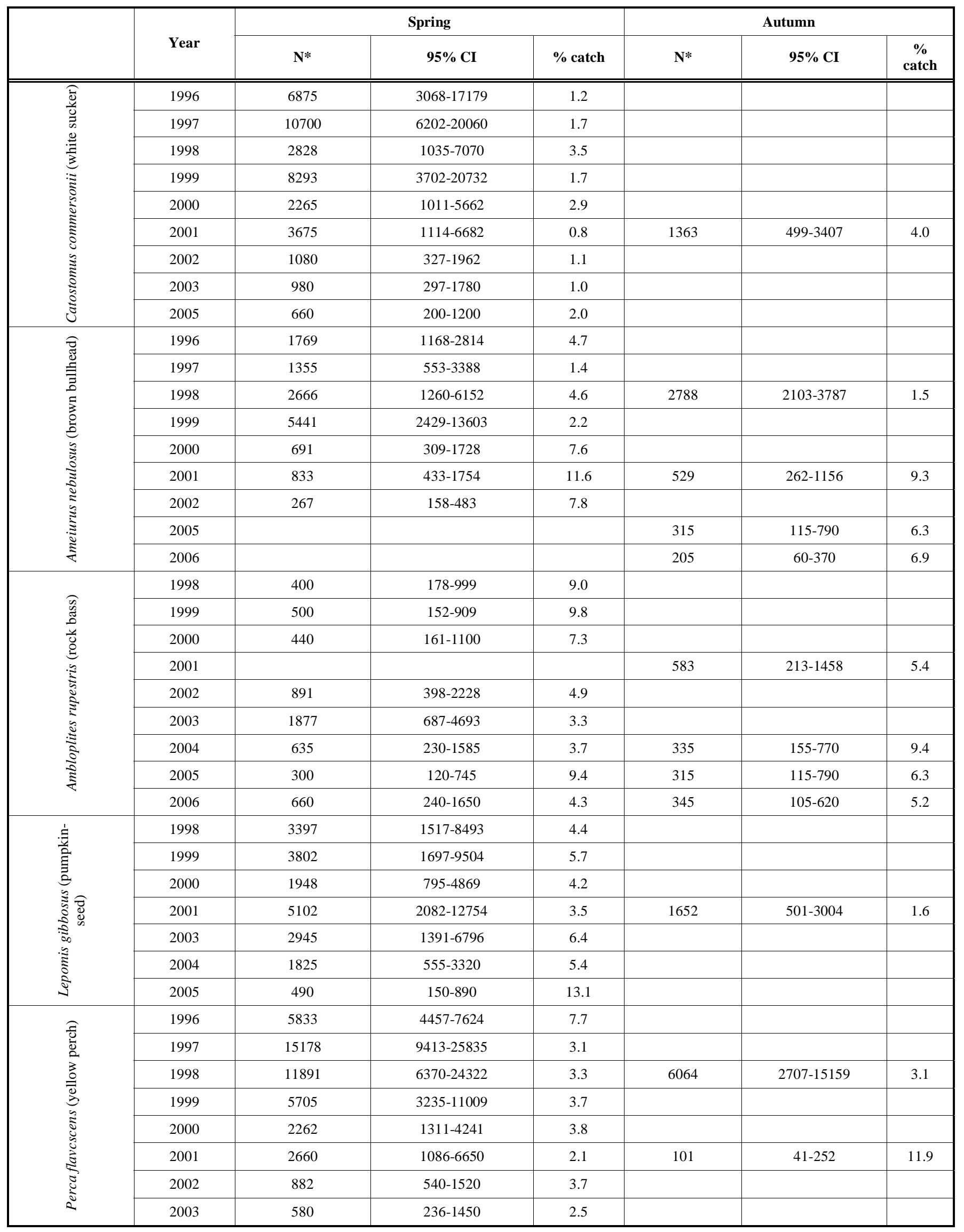




\section{DISCUSSION}

Adirondack lakes are a mixture of engineered fish assemblages [11]. Neighboring lakes, connected by relatively short stretches of stream, often have assemblages composed of entirely different species. Lakes with fish assemblages composed of only native fishes are rare, in fact, what constitutes a native assemblage is problematic because fish were introduced before any careful documentation of fish distribution was undertaken $[8,24]$.

The condition of fish populations in the lakes varies widely. In most lakes presence of multiple size classes of the common species and most rare species suggests that these populations are self sustaining. Modal lengths of the size classes within species were comparable and roughly matched those reported elsewhere [25] for populations in northern latitude lakes. We also observed reproductively active fish during our spring sampling in all lakes. However, other characteristics suggested that the condition of many assemblages in many lakes were not healthy. Of the five highDOC lakes, Helldiver and West ponds and Raquette Lake Reservoir were dominated by brown bullhead and showed low diversity, ranging from $0-0.67$ (Table 1). Although the diversity of Wheeler Pond and Sagamore Lake was relatively high, both had very low CPUE values (Table 1) and there was no evidence of young size classes in the species in Wheeler Pond. The thin till lakes were at high elevations (range $555-645 \mathrm{~m}$ ) with low diversity and richness. G Lake, dominated by a stunted brown bullhead population was the weakest assemblage in this group. The weakest assemblage of the intermediate till lakes was Round Pond with low richness, low diversity (Table 1) and dominated by a stunted population of pumpkinseed. As a seepage lake Round Pond lacked both in- and out-migration routes, which may account for the low richness and over abundance of the dominant species. Despite relatively high richness and diversity in the other intermediate till lakes, stunting was a problem in Middle Branch Lake. Willis Pond and Cascade and Sunday lakes had low CPUE (Table 1). The long-term study lakes were rich and diverse, although assemblage components and relative abundance varied among years throughout the study (Figs. 2-7).

The one characteristic that 17 of the 18 sample lakes share is that exotic species are the important, often dominant, components of the assemblage. Presence of exotic species in an assemblage reduces biological integrity [26] and, depending on which exotic species are present, can affect the status of many native species [e.g., 27]. Each of the sample lakes had been surveyed earlier (Table 6) and additional information on specific lakes has been published [28-31].

Seventeen fish assemblages were altered by an introduction or invasion by exotic species, the loss of a native species, or both (Table 7). There was an average overlap of 63\% between assemblages present in the lakes in the 1980s to those present in the 1990s and 2000s. In lakes where the results of three surveys are available, the change is even more dramatic. Assemblage components changed in the five decades between the 1930s and 1980s with an average overlap of $40 \%$, suggesting that much of the activity that led to the alteration of the original assemblages happened during the mid-twentieth century. An examination of stocking records (unpubl. Department of Environmental Conservation) offers the obvious explanation for the observed changes-the introduction of species from a suite of large, piscivores was common. However, official stocking records are not adequate to describe the extent of the alterations in that unsanctioned stocking [e.g. 30] and bait bucket introductions [e.g., 32] may have been common. The effect was two-fold, exotic species were introduced and that, in some cases, may have led to a loss of native fishes [15, 27].

The species present in these lakes in the 1930s but absent for the catches of this survey include several rare or protected fish (Table 6). Round whitefish, a state-endangered species [33] that was present in the 1930s, is extirpated from these lakes. Also absent from the later surveys are finescale dace and brook stickleback. Longnose sucker, reported as abundant in Dart and Sagamore Lakes and present in several other lakes in the 1930s, was represented in our catches by three individuals from Sagamore Lake. Lake whitefish, widely stocked during the 1930s and present in the sample lakes, has not persisted. Loss of dominance in an assemblage was also prevalent. Native fishes, such as common shiner and white sucker, were the species caught most frequently in the 1930s but they have been replaced by species like pumpkinseed and yellow perch in the 1990s and 2000s. Declines in abundance and range contraction are reported for other species throughout the Adirondack Region [6].

Numerous species have gained access to these lakes over the last several decades. Yellow perch and brown bullhead were rare or absent from most of these lakes in the 1930s (Table 6). Pumpkinseed and golden shiner were rare. These four species are abundant in our sample lakes and throughout the region in surveys conducted in the 1980s, 1990s and 2000s (e.g., Table 1) [6]. The list of species new to our sample lakes is high. Fathead minnow, central mudminnow, rainbow smelt, banded killifish, rock bass and largemouth bass were absent in these lakes in the 1930s samples, although all were present in the watersheds at that time $[2,4]$.

The impacts of the introduced fish are mixed. In lakes like Middle Branch Lake and Round Pond, the introduction of pumpkinseed led to large populations of severely stunted fish. Neither lake had near-shore predatory fishes during our sampling. The post-1984 introduction of largemouth bass into Wheeler Pond led to a precipitous decline in numbers of fish and the loss of the column-dwelling golden shiner, creek chub, brook trout and yellow perch. We also caught few small fish in this lake, which suggests that annual recruitment for most species had limited success. The undocumented introduction of largemouth bass into Wheeler Pond had occurred within a relatively short time before our sample so the extent of its impact on the assemblage may have not been fully realized. Nonetheless, the percentage overlap of species between samples in Wheeler Pond was the lowest in our study (Table 7) and it converted from a typical coldwater assemblage to a warm-water assemblage. Another lake in the sample, Willis Pond, has a warm-water fish assemblage that developed prior to the sampling in the 1930s. The assemblage has changed little among samples over seven decades (Table 7) but fish abundance was extremely low during our survey (Table 2). A possible scenario of the future of Wheeler Pond is a warm-water assemblage with low 


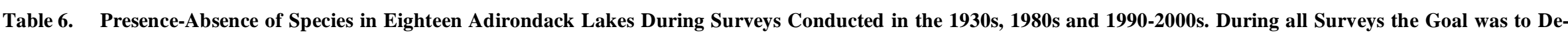
velop a Complete Species List and Specimens often were Preserved and Vouchered. Although Methods were not Consistent Among Survey Periods, the Effort to Develop as Complete a Species List as Possible was Met Using a Variety of Sampling Gear and Sampling at Varied Locations

\begin{tabular}{|c|c|c|c|c|c|c|c|c|c|c|c|c|c|c|c|c|c|c|c|c|c|c|c|c|c|c|c|c|c|c|c|c|c|c|c|c|c|c|c|c|c|c|c|c|c|}
\hline Lake & & 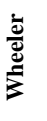 & & 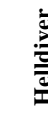 & 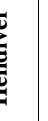 & $\bar{g}$ & & & 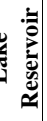 & & 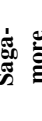 & & & ט & 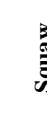 & & & $\overline{\bar{B}}$ & & & 咅 & & & 产 & & & 童 & & $\begin{array}{l}\stackrel{\varrho}{\bar{z}} \\
:\end{array}$ & 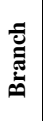 & & כֶ, & 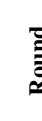 & 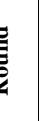 & & 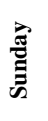 & & $\sum_{0}^{y}$ & & & $\stackrel{\overrightarrow{\tilde{I}}}{\tilde{\Xi}}$ & & & 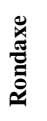 & \\
\hline Year & $\vec{\Omega}$ & 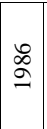 & $\overrightarrow{\widetilde{d}}$ & $\begin{array}{l} \pm \\
\stackrel{0}{\sigma} \\
=\end{array}$ & 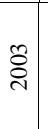 & 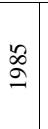 & ڤ్రి & $\stackrel{2}{\infty}$ & ర్ & & $\begin{array}{l}\stackrel{\circ}{2} \\
\cong\end{array}$ & & 志 & ஃั & $\begin{array}{l}\text { 总 } \\
\stackrel{2}{二}\end{array}$ & Әे & $\bar{\Omega}$ & $\begin{array}{l}\hat{\infty} \\
\stackrel{\sigma}{\sigma}\end{array}$ & $\stackrel{\infty}{\stackrel{\infty}{\sigma}}$ & $\bar{\Omega}$ & $\begin{array}{c}\widehat{\infty} \\
\stackrel{-}{\sigma}\end{array}$ & 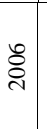 & $\tilde{\sigma}$ & $\begin{array}{l}\stackrel{\infty}{\sigma} \\
\stackrel{2}{2}\end{array}$ & $\underset{\overbrace{}}{్}$ & $\bar{\Xi}$ & 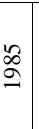 & ષ્ণ & $\begin{array}{l} \pm \\
\stackrel{0}{二} \\
\stackrel{2}{2}\end{array}$ & 气 & $\begin{array}{l} \pm \\
\stackrel{\Xi}{二}\end{array}$ & 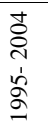 & $\begin{array}{l} \pm \\
\stackrel{0}{0} \\
\varrho\end{array}$ & 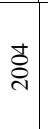 & $\overrightarrow{\check{\Omega}}$ & $\begin{array}{l}\stackrel{0}{\circ} \\
\stackrel{2}{二}\end{array}$ & ڤ్రి & $\stackrel{\circ}{\stackrel{一}{2}}$ & 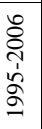 & $\bar{\Omega}$ & 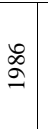 & 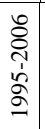 & $\bar{\sigma}$ & 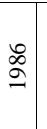 & 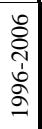 \\
\hline Couesius plumbeus & & & & & & & & & & & & $\mathrm{x}$ & & & & & $\mathrm{x}$ & $\mathrm{x}$ & $\mathrm{x}$ & $\mathrm{x}$ & $\mathrm{x}$ & & & & & & & & & & & & & & & & & & & $\mathrm{x}$ & & & & & \\
\hline Luxilus cornutus & & & & & & & & & & $\mathrm{x}$ & $\mathrm{x}$ & & $\mathrm{x}$ & & & & & & & & & & & & & & & & $\mathrm{x}$ & & & $\mathrm{x}$ & & & & & & $\mathrm{x}$ & $\mathrm{X}$ & $\mathrm{x}$ & $\mathrm{x}$ & $\mathrm{x}$ & $\mathrm{x}$ & $\mathrm{x}$ & $\mathrm{x}$ \\
\hline Luxilus X Semotilus & & & & & & & & & & & & & & & & & & & & & & & & & & & & & & & & & & & & & & & $\mathrm{X}$ & & & $\mathrm{x}$ & & & $\mathrm{x}$ \\
\hline Notemigonus crysoleucas & & $\mathrm{x}$ & & $\mathrm{x}$ & $\mathrm{x}$ & & & & & & & & & $\mathrm{x}$ & & & & & & & $\mathrm{x}$ & $\mathrm{x}$ & & $\mathrm{x}$ & $\mathrm{x}$ & & $\mathrm{x}$ & $\mathrm{x}$ & $\mathrm{x}$ & $\mathrm{x}$ & & $\mathrm{X}$ & & & & $\mathrm{x}$ & $\mathrm{x}$ & $\mathrm{x}$ & $\mathrm{X}$ & & $\mathrm{x}$ & $\mathrm{x}$ & & & $\mathrm{x}$ \\
\hline Phoxinus eos & & & & & & & & & & & & & & & & & & & & & & & & & & & & & & $\mathrm{x}$ & & & & & & & & & $\mathrm{X}$ & & & & $\mathrm{x}$ & & \\
\hline Phoxinus neogaeus & & & & & & & & & & & & & & & & & & & & & & & & & & & & & & & & & & & & & & & & & & & $\mathrm{x}$ & & \\
\hline Pimephales promelas & & & & & & & & & & & & & & & & & & & & & & & & & & & & & & $\mathrm{x}$ & & & & & & & & & & & & & & & \\
\hline Rhinichthys atratulus & & & & & & & & & & & & $\mathrm{x}$ & & & & $\mathrm{X}$ & & & & & & & & & & & & & & & & & & & & & & & $\mathrm{X}$ & & & & $\mathrm{x}$ & & \\
\hline Semotilus atromaculatus & & $\mathrm{x}$ & & $x$ & & & & & & & & $\mathrm{x}$ & & & $\mathrm{x}$ & $\mathrm{X}$ & $\mathrm{x}$ & & $\mathrm{x}$ & $\mathrm{X}$ & $\mathrm{X}$ & $\mathrm{x}$ & & & & $\mathrm{x}$ & & $\mathrm{x}$ & $\mathrm{X}$ & $\mathrm{x}$ & & $\mathrm{X}$ & & & $\mathrm{x}$ & & & & $\mathrm{X}$ & $\mathrm{X}$ & $\mathrm{x}$ & $\mathrm{x}$ & $\mathrm{X}$ & $\mathrm{x}$ & $\mathrm{x}$ \\
\hline Catostomus catostomus & $\mathrm{X}$ & & & & & & & & & & & $\mathrm{x}$ & & & & & & & & & & & & & & & & & & & & & & & & & & & & $\mathrm{X}$ & & & & & \\
\hline Catostomus commersonii & $\mathrm{X}$ & $\mathrm{x}$ & $\mathrm{X}$ & $\mathrm{x}$ & & & & & & & & $\mathrm{x}$ & & & & & $\mathrm{X}$ & $\mathrm{x}$ & & $\mathrm{X}$ & $\mathrm{x}$ & $\mathrm{x}$ & & & & $\mathrm{x}$ & $\mathrm{x}$ & $\mathrm{x}$ & $\mathrm{X}$ & $\mathrm{x}$ & $\mathrm{x}$ & $\mathrm{X}$ & & & $\mathrm{x}$ & $\mathrm{x}$ & $\mathrm{x}$ & $\mathrm{X}$ & $\mathrm{X}$ & $\mathrm{X}$ & $\mathrm{x}$ & $\mathrm{x}$ & $\mathrm{X}$ & $\mathrm{x}$ & $\mathrm{x}$ \\
\hline Catostomus utawana & & & & & & & & & & & & & & & $\mathrm{X}$ & $\mathrm{X}$ & & & & & & & & & & & & & & & & & & & & & & & & & & & & & \\
\hline Ameiurus nebulosus & $\mathrm{X}$ & $\mathrm{x}$ & $\mathrm{X}$ & $\mathrm{X}$ & $\mathrm{x}$ & $\mathrm{x}$ & $\mathrm{X}$ & $\mathrm{X}$ & $\mathrm{X}$ & & $\mathrm{X}$ & $\mathrm{X}$ & $\mathrm{X}$ & $\mathrm{X}$ & & & & $\mathrm{x}$ & $\mathrm{X}$ & $\mathrm{X}$ & $\mathrm{x}$ & $\mathrm{x}$ & $\mathrm{x}$ & $\mathrm{x}$ & $\mathrm{x}$ & $\mathrm{x}$ & $\mathrm{X}$ & $\mathrm{x}$ & $\mathrm{x}$ & $\mathrm{x}$ & $\mathrm{x}$ & $\mathrm{X}$ & & & $\mathrm{x}$ & $\mathrm{x}$ & $\mathrm{x}$ & $\mathrm{X}$ & $\mathrm{X}$ & $\mathrm{x}$ & $\mathrm{x}$ & $\mathrm{x}$ & $\mathrm{X}$ & $\mathrm{x}$ & $\mathrm{x}$ \\
\hline Esox niger & & & & & & & & & & & & & & & & & & & & & & & $\mathrm{x}$ & & $\mathrm{x}$ & & & & & & & & & & & & $\mathrm{x}$ & & & & & & & & \\
\hline Umbra limi & & & $\mathrm{X}$ & & & & & & & & & & & & & & & & & & & & & & & & & & $\mathrm{x}$ & $\mathrm{x}$ & & & $\mathrm{x}$ & $\mathrm{x}$ & & & & $\mathrm{x}$ & $\mathrm{X}$ & & & $\mathrm{x}$ & & $\mathrm{x}$ & \\
\hline Osmerus mordax & & & & & & & & & & & & & & & & & & & & & & & & & & & & & & & & & & & & & & & $\mathrm{X}$ & & & & & & $\mathrm{x}$ \\
\hline Coregonus clupeaformis & & & & & & & & & & & & & & & & & $\mathrm{X}$ & & & & & & & & & $\mathrm{x}$ & & & & & & & & & & & & & & $\mathrm{X}$ & & & $\mathrm{X}$ & & \\
\hline Prosopium cylindraceum & & & & & & & & & & & & & & & & & & & & & & & & & & $\mathrm{x}$ & & & & & & & & & & & & & & & & & & & \\
\hline Oncorhynchus mykiss & & & & & & & & & & & & & & & & & $\mathrm{x}$ & & & & & & & & & & & & & & & & & & & & & & & & & & & & \\
\hline Salmo salar & & & & & & & & & & & & & & & & & & & & & & & & & & & & & & & & & & & & & & & $\mathrm{X}$ & & & & $\mathrm{X}$ & & \\
\hline Salmo trutta & & & & & & & & & & & & & & & & & & & & & & & & & & & & & & & & & & & & & & & $\mathrm{X}$ & & & & & & \\
\hline Salvelinus fontinalis & $\mathrm{X}$ & $\mathrm{x}$ & & & $\mathrm{x}$ & $\mathrm{x}$ & & $\mathrm{X}$ & $\mathrm{x}$ & & & $\mathrm{X}$ & $\mathrm{x}$ & $\mathrm{x}$ & $\mathrm{x}$ & $\mathrm{X}$ & $\mathrm{x}$ & $\mathrm{x}$ & $\mathrm{x}$ & $\mathrm{X}$ & $\mathrm{X}$ & $\mathrm{x}$ & & & & $\mathrm{x}$ & & & $\mathrm{X}$ & $\mathrm{x}$ & $\mathrm{x}$ & $\mathrm{X}$ & & & & & & $\mathrm{x}$ & $\mathrm{X}$ & $\mathrm{X}$ & $\mathrm{x}$ & $\mathrm{X}$ & $\mathrm{X}$ & $\mathrm{x}$ & $\mathrm{x}$ \\
\hline Salvelinus namaycush & & & & & & & & & & $\mathrm{x}$ & & & & & & & $\mathrm{x}$ & & & & & & & & & $\mathrm{x}$ & & & & & & & & & & & & & & & & & & & \\
\hline S. fontinalis $\mathrm{X}$ namaycush & & & & & & & & & & & & & & & & & & & & & & & & & & & $\mathrm{x}$ & $\mathrm{x}$ & & & & & & & & & & & & & & & & & \\
\hline Fundulus diaphanus & & & & & & & & & & & & & & & & & & & & & & & & & & & & $\mathrm{x}$ & & & & & & & & & & & & & $\mathrm{x}$ & $\mathrm{x}$ & & $\mathrm{x}$ & $\mathrm{x}$ \\
\hline Culaea inconstans & & & & & & & & & & & & & & & & & & & & & & & & & & & & & & & & & & & & & & & & & & & $\mathrm{X}$ & & \\
\hline Ambloplites rupestris & & & & & & & & & & & & & & & & & & & & & & & & & & & $\mathrm{x}$ & $\mathrm{x}$ & & & & & & & & & & & $\mathrm{X}$ & & & $\mathrm{x}$ & & $\mathrm{x}$ & $\mathrm{x}$ \\
\hline
\end{tabular}


(Table 6). contd....

\begin{tabular}{|c|c|c|c|c|c|c|c|c|c|c|c|c|c|c|c|c|c|c|c|c|c|c|c|c|c|c|c|c|c|c|c|c|c|c|c|c|c|c|c|c|c|c|c|c|}
\hline Lake & & 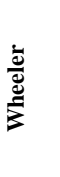 & & 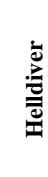 & & 莺 & & 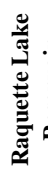 & & & 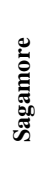 & & 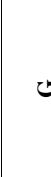 & & $\frac{\bar{J}}{\bar{n}}$ & & & 志 & & 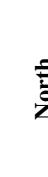 & & & $\stackrel{n}{\frac{n}{2}}$ & & & 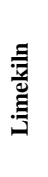 & & 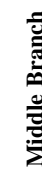 & & 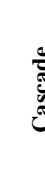 & & 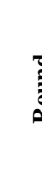 & & & 胥 & & 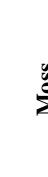 & $\hat{s}$ & & تِ & & & 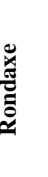 & \\
\hline Year & $\bar{\Omega}$ & $\mid \begin{array}{l}0 \\
\stackrel{2}{9}\end{array}$ & $\overline{\mathrm{D}}$ & 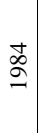 & ᄋ్ণ & 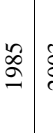 & ڤ్రి & 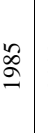 & ర్సి & $\stackrel{\check{\Omega}}{\Omega}$ & $\begin{array}{l}\circ \\
\stackrel{\circ}{\circ} \\
\stackrel{2}{2}\end{array}$ & $\hat{\sigma}$ & 志 & よे & $\begin{array}{l}\text { ț } \\
\stackrel{2}{\Omega}\end{array}$ & बे & $\vec{\sigma}$ & 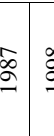 & סू & 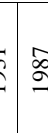 & ঃั & $\widetilde{\Omega}$ & $\begin{array}{l}\infty \\
\stackrel{0}{\sigma}\end{array}$ & ठ̊. & $\bar{\sigma}$ & $\stackrel{\infty}{\varrho}$ & ষ্ণী & $\stackrel{+}{\stackrel{\infty}{\varrho}}$ & $\stackrel{2}{\sigma}$ & 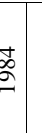 & 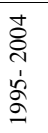 & $\begin{array}{l}+ \\
\stackrel{+}{2}\end{array}$ & 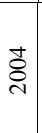 & $\bar{\sigma}$ & $\begin{array}{l}\stackrel{\circ}{\circ} \\
\stackrel{2}{二}\end{array}$ & ڤ్ & 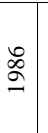 & 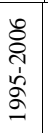 & $\bar{g}$ & $\stackrel{\circ}{\stackrel{\infty}{\varrho}}$ & 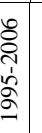 & $\bar{\sigma}$ & 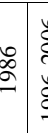 & \\
\hline Lepomis gibbosus & & $\mathrm{x}$ & $\mathrm{x}$ & & & & & & & $\mathrm{x}$ & & $\mathrm{X}$ & $\mathrm{x}$ & & & & & & & & & $\mathrm{x}$ & $\mathrm{x}$ & $\mathrm{x}$ & $\mathrm{x}$ & $\mathrm{x}$ & $\mathrm{x}$ & $\mathrm{x}$ & $\mathrm{x}$ & & $\mathrm{X}$ & $\mathrm{x}$ & $\mathrm{x}$ & $\mathrm{x}$ & & & $\mathrm{x}$ & $\mathrm{x}$ & $\mathrm{x}$ & & $\mathrm{X}$ & $\mathrm{x}$ & $\mathrm{x}$ & $\mathrm{x}$ \\
\hline Micropterus dolomieu & & & & & & & & & & $\mathrm{x}$ & & & & & & & & & & & & $\mathrm{x}$ & & & & & & & & & & & & & & & & & & & $\mathrm{x}$ & $\mathrm{x}$ & thata & $\mathrm{x}$ \\
\hline Micropterus salmoides & & & $\mathrm{x}$ & & & & & & & & & & & & & & & & & & & & $\mathrm{x}$ & $\mathrm{x}$ & & & & & & & & & & & & & & $\mathrm{x}$ & & & $\mathrm{x}$ & & & $\mathrm{x}$ \\
\hline Perca flavescens & & $\mathrm{x}$ & & & & & & & & & $\mathrm{X}$ & $\mathrm{X}$ & & & & & & & & & $\mathrm{x}$ & $\mathrm{x}$ & $\mathrm{x}$ & $\mathrm{x}$ & & $\mathrm{x}$ & $\mathrm{X}$ & & & $\mathrm{x}$ & $\mathrm{x}$ & & & & $\mathrm{x}$ & $\mathrm{x}$ & $\mathrm{x}$ & $\mathrm{x}$ & & $\mathrm{x}$ & $\mathrm{x}$ & & $\mathrm{x}$ & $\mathrm{x}$ \\
\hline
\end{tabular}

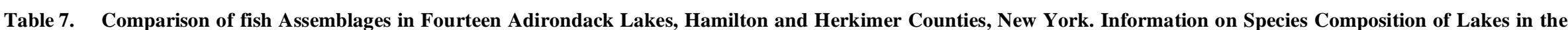
1930s is from the Watershed Survey Reports [2], [3], [4], [5] and from Original Field Catalogues Housed at the New York State Museum. Information on Species Composition in the 1980s is from the ALSC (Unpubl. Rept.).

\begin{tabular}{|c|c|c|c|c|c|c|c|c|c|c|c|c|c|c|c|c|}
\hline \multirow[t]{2}{*}{ Lake } & \multicolumn{2}{|c|}{ 1930s } & \multirow[b]{2}{*}{$\begin{array}{c}\text { Number } \\
\text { lost }\end{array}$} & \multirow[b]{2}{*}{$\begin{array}{l}\text { Number } \\
\text { gained }\end{array}$} & \multicolumn{2}{|c|}{ 1980s } & \multirow[b]{2}{*}{$\begin{array}{c}\text { Number } \\
\text { lost }\end{array}$} & \multirow[b]{2}{*}{$\begin{array}{c}\text { Number } \\
\text { gained }\end{array}$} & \multicolumn{2}{|c|}{$1990 \mathrm{~s}-2000 \mathrm{~s}$} & \multirow[b]{2}{*}{$\begin{array}{c}\text { Similarity } \\
1930 \text { s- } \\
1980 \text { s }\end{array}$} & \multirow[b]{2}{*}{$\begin{array}{c}\text { Similarity } \\
\text { 1980s- } \\
1990-00 \text { s }\end{array}$} & \multirow[b]{2}{*}{$\begin{array}{c}\text { Similarity } \\
1930 \text { s- } \\
1990-00 s\end{array}$} & \multirow[b]{2}{*}{$\begin{array}{c}\text { Number } \\
\text { of species } \\
\text { present } \\
\text { in } 1 \\
\text { survey } \\
\text { only }\end{array}$} & \multirow[b]{2}{*}{ 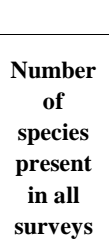 } & \multirow[b]{2}{*}{$\begin{array}{c}\text { Number } \\
\text { of species } \\
\text { reported } \\
\text { from } \\
\text { lake }\end{array}$} \\
\hline & Richness & $\begin{array}{c}\text { Dominant } \\
\text { species }\end{array}$ & & & Richness & $\begin{array}{c}\text { Dominant } \\
\text { species }\end{array}$ & & & Richness & $\begin{array}{c}\text { Dominant } \\
\text { species }\end{array}$ & & & & & & \\
\hline G & 4 & $\begin{array}{l}\text { Luxilus } \\
\text { cornutus }\end{array}$ & 3 & 2 & 3 & $\begin{array}{l}\text { Salvelinus } \\
\text { fontinalis }\end{array}$ & 1 & 1 & 3 & $\begin{array}{l}\text { Notemigonus } \\
\text { crysoleucas }\end{array}$ & 0.16 & 0.50 & 0.40 & 3 & 1 & 6 \\
\hline Sagamore & 9 & $\begin{array}{l}\text { Luxilus } \\
\text { cornutus }\end{array}$ & 4 & 3 & 8 & $\begin{array}{l}\text { Catostomus } \\
\text { commer- } \\
\text { sonii }\end{array}$ & 2 & 3 & 9 & $\begin{array}{l}\text { Catostomus } \\
\text { commersonii }\end{array}$ & 0.41 & 0.54 & 0.50 & 4 & 4 & 13 \\
\hline $\begin{array}{l}\text { Raquette } \\
\text { Res }\end{array}$ & & & & & 2 & $\begin{array}{l}\text { Ameiurus } \\
\text { nebulosus }\end{array}$ & 0 & 0 & 2 & $\begin{array}{l}\text { Ameiurus } \\
\text { nebulosus }\end{array}$ & & 1.00 & & 0 & 2 & 2 \\
\hline South & 7 & $\begin{array}{l}\text { Catostomus } \\
\text { commersonii }\end{array}$ & 3 & 1 & 5 & $\begin{array}{l}\text { Catostomus } \\
\text { commer- } \\
\text { sonii }\end{array}$ & 1 & 0 & 4 & $\begin{array}{l}\text { Couesius } \\
\text { plumbeus }\end{array}$ & 0.50 & 0.80 & 0.44 & 3 & 2 & 8 \\
\hline North & 6 & $\begin{array}{l}\text { Catostomus } \\
\text { commersonii }\end{array}$ & 1 & 1 & 6 & $\begin{array}{l}\text { Catostomus } \\
\text { commer- } \\
\text { sonii }\end{array}$ & 3 & 1 & 4 & $\begin{array}{c}\text { Perca } \\
\text { flavescens }\end{array}$ & 0.71 & 0.43 & 0.25 & 3 & 2 & 8 \\
\hline
\end{tabular}


(Table 7) contd........

\begin{tabular}{|c|c|c|c|c|c|c|c|c|c|c|c|c|c|c|c|c|}
\hline \multirow[t]{2}{*}{ Lake } & \multicolumn{2}{|c|}{ 1930s } & \multirow[b]{2}{*}{$\begin{array}{c}\text { Number } \\
\text { lost }\end{array}$} & \multirow[b]{2}{*}{$\begin{array}{l}\text { Number } \\
\text { gained }\end{array}$} & \multicolumn{2}{|c|}{$1980 \mathrm{~s}$} & \multirow[b]{2}{*}{$\begin{array}{l}\text { Number } \\
\text { lost }\end{array}$} & \multirow[b]{2}{*}{$\begin{array}{c}\text { Number } \\
\text { gained }\end{array}$} & \multicolumn{2}{|c|}{$1990 \mathrm{~s}-2000 \mathrm{~s}$} & \multirow[b]{2}{*}{$\begin{array}{c}\text { Similarity } \\
\text { 1930s- } \\
1980 \mathrm{~s}\end{array}$} & \multirow[b]{2}{*}{$\begin{array}{c}\text { Similarity } \\
1980 \text { s- } \\
1990-00 s\end{array}$} & \multirow[b]{2}{*}{$\begin{array}{c}\text { Similar- } \\
\text { ity } \\
\text { 1930s- } \\
\text { 1990-00s }\end{array}$} & \multirow[b]{2}{*}{$\begin{array}{c}\text { Number } \\
\text { of species } \\
\text { present } \\
\text { in } 1 \\
\text { survey } \\
\text { only }\end{array}$} & \multirow[b]{2}{*}{ 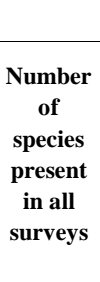 } & \multirow[b]{2}{*}{$\begin{array}{c}\text { Number } \\
\text { of spe- } \\
\text { cies } \\
\text { re- } \\
\text { ported } \\
\text { from } \\
\text { lake }\end{array}$} \\
\hline & Richness & $\begin{array}{c}\text { Dominant } \\
\text { species }\end{array}$ & & & Richness & $\begin{array}{c}\text { Dominant } \\
\text { species }\end{array}$ & & & Richness & $\begin{array}{c}\text { Dominant } \\
\text { species }\end{array}$ & & & & & & \\
\hline Limekiln & 8 & $\begin{array}{l}\text { Catostomus } \\
\text { commersonii }\end{array}$ & 5 & 4 & 7 & $\begin{array}{l}\text { Ameiurus } \\
\text { nebulosus }\end{array}$ & 0 & 2 & 9 & $\begin{array}{l}\text { Lepomis } \\
\text { gibbosus }\end{array}$ & 0.27 & 0.77 & 0.31 & 5 & 3 & 12 \\
\hline Squaw & & & & & 3 & $\begin{array}{l}\text { Catostomus } \\
\text { utawana }\end{array}$ & 0 & 1 & 4 & $\begin{array}{c}\text { Catostomus } \\
\text { utawana }\end{array}$ & & 0.75 & & 1 & 3 & 4 \\
\hline Helldiver & & & & & 4 & $\begin{array}{l}\text { Ameiurus } \\
\text { nebulosus }\end{array}$ & 2 & 1 & 3 & $\begin{array}{l}\text { Notemigonus } \\
\text { crysoleucas }\end{array}$ & & 0.40 & & 3 & 2 & 5 \\
\hline $\begin{array}{l}\text { Middle } \\
\text { Branch }\end{array}$ & & & & & 7 & $\begin{array}{l}\text { Catostomus } \\
\text { commersonii }\end{array}$ & 1 & 2 & 8 & $\begin{array}{l}\text { Lepomis } \\
\text { gibbosus }\end{array}$ & & 0.66 & & 3 & 6 & 9 \\
\hline Cascade & & & & & 4 & $\begin{array}{c}\text { Perca } \\
\text { flavescens }\end{array}$ & 0 & 4 & 8 & $\begin{array}{l}\text { Perca flaves- } \\
\text { cens }\end{array}$ & & 0.50 & & 4 & 4 & 8 \\
\hline Moss & & & & & 8 & $\begin{array}{c}\text { Perca } \\
\text { flavescens }\end{array}$ & 0 & 9 & 18 & $\begin{array}{l}\text { Luxilus } \\
\text { cornutus }\end{array}$ & & 0.47 & & 10 & 8 & 18 \\
\hline Dart & 10 & $\begin{array}{l}\text { Luxilus } \\
\text { cornutus }\end{array}$ & 5 & 3 & 8 & $\begin{array}{c}\text { Catostomus } \\
\text { commersonii }\end{array}$ & 0 & 7 & 15 & $\begin{array}{l}\text { Perca flaves- } \\
\text { cens }\end{array}$ & 0.38 & 0.53 & 0.30 & 10 & 5 & 19 \\
\hline Rondaxe & 13 & $\begin{array}{l}\text { Ameiurus } \\
\text { nebulosus }\end{array}$ & 7 & 4 & 10 & $\begin{array}{l}\text { Catostomus } \\
\text { commersonii }\end{array}$ & 1 & 6 & 15 & $\begin{array}{l}\text { Perca flaves- } \\
\text { cens }\end{array}$ & 0.37 & 0.56 & 0.35 & 11 & 6 & 22 \\
\hline West & & & & & 2 & $\begin{array}{l}\text { Ameiurus } \\
\text { nebulosus }\end{array}$ & 1 & 0 & 1 & $\begin{array}{l}\text { Ameiurus } \\
\text { nebulosus }\end{array}$ & & 0.50 & & 1 & 1 & 2 \\
\hline Sunday & 4 & $\begin{array}{l}\text { Lepomis } \\
\text { gibbosus }\end{array}$ & 2 & 2 & 4 & $\begin{array}{l}\text { Catostomus } \\
\text { commersonii }\end{array}$ & 0 & 1 & 5 & $\begin{array}{l}\text { Ameiurus } \\
\text { nebulosus }\end{array}$ & 0.33 & 0.80 & 0.29 & 3 & 2 & 7 \\
\hline Wheeler & & & & & 7 & $\begin{array}{l}\text { Notemigonus } \\
\text { crysoleucas }\end{array}$ & 4 & 2 & 5 & $\begin{array}{l}\text { Lepomis } \\
\text { gibbosus }\end{array}$ & & 0.33 & & 6 & 3 & 9 \\
\hline Round & & & & & 2 & $\begin{array}{l}\text { Lepomis } \\
\text { gibbosus }\end{array}$ & 0 & 0 & 2 & $\begin{array}{l}\text { Lepomis } \\
\text { gibbosus }\end{array}$ & & 1.00 & & 0 & 2 & 2 \\
\hline Willis & 5 & $\begin{array}{l}\text { Lepomis } \\
\text { gibbosus }\end{array}$ & 2 & 2 & 5 & $\begin{array}{l}\text { Notemigonus } \\
\text { crysoleucas }\end{array}$ & 0 & 1 & 6 & $\begin{array}{l}\text { Perca flaves- } \\
\text { cens }\end{array}$ & 0.43 & 0.83 & 0.57 & 1 & 3 & 7 \\
\hline
\end{tabular}


abundance. The striking similarity among the three lakes dominated by warm-water fish was the low number of fish caught. The introduction of largemouth bass into Rondaxe Lake during the study demonstrated that the introduction of this species had an extensive and rapid impact on the established assemblage (Figs. 6 and 7).

Fish assemblages have changed in most of the eighteen sample lakes between the 1930s and recent times. Baker et al. [34] suggested that change in fish assemblage structure in Adirondack lakes may be related to changes in the physicochemical environment, specifically decreasing $\mathrm{pH}$. Brook trout and acid-sensitive minnows are the species most affected by declining $\mathrm{pH}$. Many of the extirpated native species are identified as acid-intolerant and are absent from lakes with $\mathrm{pH}<5.5$ [35]. The four species now most common throughout the sample lakes, brown bullhead, golden shiner, pumpkinseed and yellow perch, also show the highest acid tolerance; each is found in lakes with $\mathrm{pH}<5$ [35]. However, other factors are important. Widespread introductions of fishes in general, and game fishes in particular, also have been demonstrated to affect abundance and distribution of fishes [27].

Another attribute of the data that could confound interpretation of these results is the lack of lake-specific historical records. Baker et al. [34] also noted the paucity and inadequacy of historical records for assessing regional changes in fish assemblages. The earlier surveys were synoptic and focused resources on sampling a large number of lakes rather than dealing with a few lakes more intensively. Synoptic surveys of fishes in lakes can provide a good assessment of the status of individual species in the region [27]. However, there may be problems with using historical data to assess within-lake changes in fish assemblages because the survey results from a single lake represent a snapshot of conditions that are affected by numerous, and often unmeasured, factors that affect catch and not assemblage. If the comparison is conservative, such as comparing presence and absence as is done here, the conclusions drawn can be of value, however.

In summary, the sample Adirondack lakes host fish assemblages largely affected by the presence of exotic species. Although fish assemblages have changed (Table 7) during a period when physico-chemical environmental conditions have also changed [34], the relationship between water chemistry and fish assemblage structure is unclear because a major confounding factor is the introduction of exotic species. In eleven of the study lakes, the number of exotic species exceeds the number of native species (Table $\mathbf{1}$ ), which is common in the area $[11,24]$. In four others, exotic and native species are equal. The number of native species exceeds that of exotics in only three study lakes (Table 1). Unique is Squaw Lake, where all four species in the assemblage are native. The assemblage includes a salmonid, a sucker and two minnows, which are species typical of upland, headwater streams [4]. This high-elevation lake, which is situated upstream of an in-stream barrier, may be a relatively rare example of a lake with an ancestral fish assemblage and was a rare find in a study dominated by lakes with fish assemblages that seem haphazardly altered [11].

\section{ACKNOWLEDGMENTS}

A long-running project relies on the help of many people over the years. We thank R. Morse, J. Harrison, B. Weatherwax, J. Bloomfield, S. Quinn, L. Eichler, D. Diehl, D. Del Sole, D. Bloomquist, I. Zellman, D. Fera, J. MacDougall, L. Baldigo, D. Petersen, J. Getbehead, and J. Tyler. This work was supported by EPA contract 68D20171.

\section{REFERENCES}

[1] Greeley JR. Fishes of the Champlain watershed. In: Moore E, Ed. A biological survey of the Champlain watershed. Supplemental to the nineteenth annual report of the New York State Conservation Department (1929), Albany, NY 1930; pp. 44-87.

[2] Greeley JR. Fishes of the Raquette watershed with an annotated list. In: Moore E, Ed. A biological survey of the Raquette watershed. Supplemental to the twenty-third annual report of the New York State Conservation Department (1923), Albany, NY 1934; pp. 53-108.

[3] Greeley JR. Fishes of the Mohawk-Hudson watershed with an annotated list. In: Moore E, Ed. A biological survey of the Mohawk-Hudson watershed. Supplemental to the twenty-fourth annual report of the New York State Conservation Department (1934), Albany, NY 1935; pp. 63-101.

[4] Greeley JR, Bishop, SC. Fishes of the watershed with annotated list. In: Moore E, Ed. A biological survey of the Oswegatchie and Black river systems. Supplemental to the twenty-first annual report of the New York State Conservation Department (1931), Albany, NY 1932; pp. 54-92.

[5] Greeley JR, Bishop, SC. Fishes of the upper Hudson watershed with annotated list. In: Moore E, Ed. A biological survey of the upper Hudson watershed. Supplemental to the twenty-second annual report of the New York State Conservation Department (1932), Albany, NY 1933; pp. 64-101.

[6] Gallagher J, Baker, J. Current status of fish communities in Adirondack Lakes. In: Adirondack Lake Survey: An interpretive analysis of fish communities and water chemistry, 1984-87, Adirondack Lake Survey Corporation, Ray Brook, NY 1990; pp. 3-113-48.

[7] DeKay JE. Zoology of New York or the New York fauna, Part IV. Fishes. W. and A. White and J. Visscher. Albany, NY 1842.

[8] Mather F. Memoranda relating to Adirondack fishes with descriptions of new species from researches made in 1882. Weed, Parsons and Company legislative printers, Albany, NY 1886.

[9] Kendall WC, Dence WA. The fishes of the Cranberry Lake Region. Roosevelt Wildl Bull 1929; 5: 219-309.

[10] George CJ. The fishes of the Adirondack Park. NY State Dept Environ Cons, Albany, NY 1981.

[11] Kays RW, Daniels RA. Fish and Wildlife Communities of the Adirondacks. In: Porter WF, Erickson JD, Whaley RS, Ed. The great experiment in conservation: voices from the Adirondack Park: Univ Syracuse Press, Syracuse, NY 2009; pp. 71-86.

[12] Nierzwicki-Bauer SA, Boylen CW, Eichler LW, Harrison JP, Sutherland JW, Shaw W, Daniels RA, Charles DF, Acker FW, Sullivan TJ, Momen B, Bukavechas P. Acidification in the Adirondacks: defining the biota in trophic levels of 30 chemically diverse acidimpacted lakes. Environ. Sci Technol 2010; 44:5721-5727.

[13] Adirondack Lake Survey Corporation (ALSC), unpubl. data, Available from: http://www.adirondacklakessurvey.org/choicepage.php. [cited: 2010]

[14] Newton RM, Driscoll CT. Classification of ALSC lakes. In: Adirondack Lake Survey: An interpretive analysis of fish communities and water chemistry, 1984-87, Adirondack Lake Survey Corporation, Ray Brook, NY 1990; pp. 2-70-2-91.

[15] Whittier TR, Halliwell DB, Paulsen SG. Cyprinid distributions in Northeast USA lakes: evidence of regional-scale minnow biodiversity losses. Can J. Fish Aquat Sci 1997; 54: 1593-607.

[16] Stickney RR. Care and handling of live fish. In: Nielsen LA, Johnson DL, Lampton SS, Ed. Fisheries techniques. Amer Fish Soc, Bethesda, MD 1983; pp. 85-94. 
[17] Wydoski R, Emery L. Tagging and marking. In: Nielsen LA, Johnson DL, Lampton SS, Ed. Fisheries techniques. Amer Fish Soc, Bethesda, MD 1983; pp. 215-238.

[18] Le Cren ED, Kipling C, McCormack JC. A study of the numbers, biomass and year-class strengths of perch (Perca fluviatilis L.) in Windermere from 1941 to 1966. J. Anim Ecol 1977; 46: 281-307.

[19] Schneider JC, Laarman PW, Gowing H. Length-weight relationship. In: Schneider JC, Ed. Manual of fisheries Survey Methods II, with periodic updates. State of Michigan, Dept. Nat. Res., Fishery Div. Spec. Rept. 25 2000; pp. (17)1-(17)16.

[20] Ricker WE. Computation and interpretation of biological statistics of fish populations. Dept Environ, Fish Mar Serv Bull 1975; 191: 1-382.

[21] Carlson DM, Daniels RA. Status of fishes in New York: increases, declines and homogenization of watersheds. Am Midl Natur 2004; 152: 104-39.

[22] New York State Department of Environmental Conservation (DEC), unpubl. data. Available from: http://www.dec.ny.gov/outdoor/30467.html [cited: 2010].

[23] Daniels RA, Morse RS, Sutherland JW, Bombard RT, Boylen CW. Fish movement among lakes: Are lakes isolated? NE Nat 2008; 15: 577-88.

[24] Stager JC, Sanger T. An Adirondack "Heritage Lake." Adirondack J Environ Studies 2003; 10: 6-10.

[25] Scott WB, Crossman EJ. Freshwater fishes of Canada. Fish Res Bd Can, Bull 184, Ottawa, ON 1973.

[26] Karr JR, Fausch KD, Angermeier PL, Yant PR, Schlosser IJ. Assessment of biotic integrity in running waters: a method and its rationale. Illinois Natural History Survey, Special Publication 5, Champaign, IL 1986.
[27] Whittier TR, Kincaid TM. Introduced fish in northeastern USA lakes: regional extent, dominance, and effect on native species richness. Trans Amer Fish Soc 1999; 128: 769-83.

[28] Faigenbaum HM. Chemical investigation of the Mohawk-Hudson watershed. In: Moore E, Ed. A biological survey of the MohawkHudson watershed. Supplemental to the twenty-fourth annual report of the New York State Conservation Department (1934), Albany, NY 1935; pp. 160-213.

[29] Goodwin KR. Sagamore Lake 1993 Study. unpubl. report to the Great Camp, Sagamore Foundation 1993.

[30] Odell TT. Lakes of the Oswegatchie and Black River systems. In: Moore E, Ed. A biological survey of the Oswegatchie and Black river systems. Supplemental to the twenty-first annual report of the New York State Conservation Department (1931), Albany, NY 1932; pp. 94-119.

[31] Pfeiffer MH, Festa PJ. Acidity status of lakes in the Adirondack Region of New York in relation to fish resources. New York State Dept of Environ Cons, Albany, NY, FW-P168 1980.

[32] Ludwig, HR, Jr, Leitch JA. Interbasin transfer of aquatic biota via anglers' bait buckets. Fisheries 1996; 21(7):14-8.

[33] Carlson DM. Species accounts for the rare fishes of New York. New York State Dept Environ Cons, Albany, NY 2001.

[34] Baker JP, Warren-Hicks WJ, Gallagher J, Christensen SW. Fish population losses from Adirondack lakes: the role of surface water acidity and acidification. Water Resource Res 1993; 29: 861-74.

[35] Driscoll CT, Newton RM, Gubala CP, Baker JP, Christensen SW. Adirondack Mountains. In: Charles DF, Christie S, Ed. Acidic deposition and aquatic ecosystems regional case studies: SpringerVerlag, New York 1991; pp. 133-202.

(C) Daniels et al.; Licensee Bentham Open.

This is an open access article licensed under the terms of the Creative Commons Attribution Non-Commercial License (http://creativecommons.org/licenses/ by-nc/3.0/) which permits unrestricted, non-commercial use, distribution and reproduction in any medium, provided the work is properly cited. 